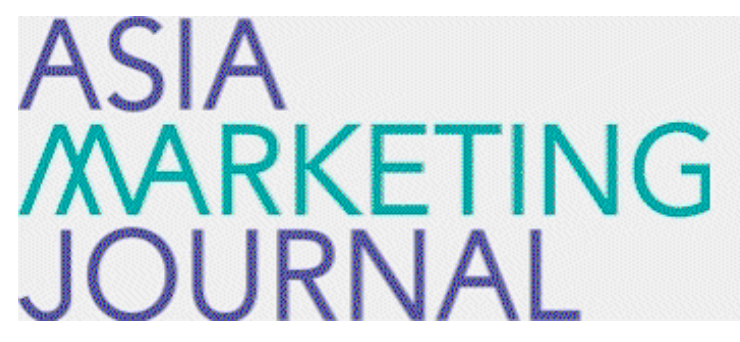

ASIA MARKETING JOURNAL

Volume 6 | Issue 1

Article 4

\title{
3-25-2004
}

\section{온라인 상거래 수용에 관한 톻합적 확장}

양환 입

세훈 박

Follow this and additional works at: https://amj.kma.re.kr/journal

Part of the Marketing Commons

\section{Recommended Citation}

입, 양환 and 박, 세훈 (2004) "온라인 상거래 수룡에 관한 톨합적 확장," Asia Marketing Journal: Vol. 6 : Iss. 1 , Article 4.

Available at: https://doi.org/10.53728/2765-6500.1123

This Article is brought to you for free and open access by Asia Marketing Journal. It has been accepted for inclusion in Asia Marketing Journal by an authorized editor of Asia Marketing Journal. 


\title{
온라인 상거래 수용에 관한 통합적 확장: 기술수용모델에 대한 신뢰와 감정의 결합*
}

\section{An Integrated Extension to On-line Commerce Acceptance: \\ A Combination of Trust and Affect into the Technology Acceptance Model}

\author{
임양환(사이버외국어대학교 $\mathrm{e}^{-}$비즈니스학과 전임강사) \\ hi2lctilycos.co. kr \\ 박세훈 (성균관대학교 경영학부 교수) \\ sehoonèskku.cdu
}

\begin{abstract}
인터넷관련 혁신의 수용을 설명하려는 많은 연구들에서 정보기술수용모댈(TAM)이 적용 되었지만, 온라인 상거래의 수용올 정확히 설명하기 위해서는 인터넷을 통해 상거래를 할 때 발생하는 특성올 반영해야 한다. 본 연구에서는 온라인 상거래관련 기존 연구들올 바 탕으로 TAM을 확장하는 변수로 신뢰와 감정을 추가하고 변수들의 영향 관계를 통합적으로 구조화하였다. 이러한 확장 구조를 통해, 온라인 상거래 수용을 설명하는데 TAM의 원형을 그대로 적용하거나 신뢰 혹은 감정만을 고려한 기존 연구들이 갖는 설명의 제한점을 극복 하고자 하였다. 그리고 온라인 상거래의 수용에 대한 전체적인 틀올 파악하고, 소비자가 온라인 상거래를 수용하는 측면에서 온라인 상거래의 성공올 결정짓는 주요한 변수들의 관계를 명확히 하였다.

신뢰, 감정, 사용의 용이함이 유용성을 지각하고 사이트 사용의도를 갖고 상거래 행동울 하는데 영향을 주며 이들 변수들간에도 영향관계가 있다는 모델을 제안하였고, 대안적으 로 감정을 태도의 요소로 보는 모델과 신뢰가 감정이 전혀 관계가 없다는 모델을 제시하 였다. 모델들올 비교한 결과 제안모델이 가장 우수하다고 판단할 수 있었다. 각 변수들의 경로계수에 의해 가설을 검증한 결과, 감정과 사용의 용이함은 유용성에 정적으로 유의하 게 영향을 주었고 신뢰는 어느 정도 영향을 주었다. 그리고 신뢰와 사용의 용이함은 감정 에도 유의하게 영향을 주었다. 그렇지만 사이트 사용의도에 유의하게 영향올 미치는 변수 는 사용의 용이함 뿐이었다. 실중연구를 바탕으로, 온라인 상거래가 사용자 수용 측면에 서 성공을 할 수 있기 위해서는 사용의 용이함과 함꼐 신뢰와 감정이 중요하게 고려되어 야 함을 알 수 있다.
\end{abstract}

\footnotetext{
* 논문접수 : 03.08 게재확정 : 04.03
}

이 논문은 2001년도 한국학술진홍재단의 지원에 의해 연구되었음(KRF-2001-005-C2001) 


\section{1. 서론}

인터넷 행동의 주체는 사람이기 때문에 인터넷을 통한 상거래는 오프라인 상거래와 공통 적인 성격을 가지고 있다 ${ }^{1}$. 그렇지만 사람들이 온라인에서 행동을 할 때는 온라인만의 환경 을 반영하는 독특한 욕구와 관심사도 나타나며 이러한 특징은 상거래에서도 반영된다. 예를 들면, 온라인 소비자는 오프라인 구매 때보다 구매 자체에 대해 더욱 강한 기대감을 갖고 많은 것을 요구하며 실용적 경향을 보이기도 한다. 그 결과로 온라인 소비자가 특정 인터넷 쇼펑몰을 애호하는 정도가 전체적으로 낮게 나타나는 경우도 있다(Koufaris 2002).

인터넷이 생활의 일부분이 되고 온라인 상거래의 비중도 커짐에 따라 다양한 방향에서 온라인 상거래의 특징을 파악하고 설명하려는 연구들이 시도되고 있다. 특히 최근에는 많은 연구들이 쏟아지고 있어서 연구들을 일일이 파악하고 분류하는 것 조차 어렵다. 그렇지만 국내에서 실시된 몇몇 연구들의 유형을 보면, 인터넷에서의 활동(예, 김기범, 김미희, 최상 진 2001; 김명소 1999, 김재휘, 홍재욱 2000), 인터넷에서의 소비자 행동(예, 김상용, 박성 용 1999; 김영찬, 이두희 2002; 김훈, 권순일 1999; 문병준, 손용석 2000; 박철 2002; 유현 정, 김기옥 2000; 이문규, 최은정 2001; 전종근, 홍성태 2003), 인터넷에서의 마케팅 믹스(예, 김재휘 2001; 이호배, 정주훈, 박기백 2000; 최인혁, 박주영, 이철선 2002) 등을 들 수 있다.

그리고 사람들이 인터넷관련 분야를 수용하는 현상을 설명하는 시도들도 하나의 연구 흐 름을 형성하고 있다. 인터넷관련 분야의 수용에 대한 연구들은 주로 기술수용모델(TAM, technology acceptance model)의 구조를 바탕으로 하는데, 이 모델은 작업현장에서 사람들이 혁신적인 시스템(새로운 애플리케이션)을 수용하는 현상을 설명하기 위해 제시된 것이다. 인터넷의 수용을 설명하는 연구들이 기술수용모델(TAM)의 구조를 적용할 수 있는 근거는 인 터넷이 정보통신기술을 바탕으로 인간생활의 환경으로 새롭게 대두되었다는 점에서 혁신적 인 기술의 한 형태에 해당하기 때문이다(Peterson et a1. 1997). TAM의 핵심 변수인 유용성 (perceived usefulness)과 사용 용이함(perceived ease of use)은 인터넷관련 분야의 수용을 설명하는 많은 연구들에서 주요한 변수로 적용되어 높은 설명력을 나타내고 있다. 그러한 연구들로는 인터넷 이용에 관한 연구(예, Chau, Au, and Tam 2000; Lederer et al. 2000), 인 터넷 활용분야의 사용에 관한 연구(예, Hong et al. 2002), 인터넷 쇼찡을 설명한 연구(예, Gefen and Straub 2000; Gefen, Karahanna, and Strub 2003; Koufaris 2002; 윤철호, 김상훈 2003), 인터넷 금융 서비스의 이용을 설명한 연구(예, 이건창, 정남호, 이종신 2002; 제진훈, 박윤재, 김광용 2002) 등이 있다.

기존의 TAM 중심의 구조를 온라인 상거래에 적용하여 인터넷 관련 분야의 수용요인을 찾 으려는 대부분의 연구들은 TAM의 원형을 그대로 적용하고 있다. 그렇지만 기존의 오프라인 응용기술을 대상으로 했던 TAM 구조에 의해 개인이 인터넷 상거래를 수용하는 현상을 설명 하기 위해서는 오프라인의 경우와 다른 인터넷의 고유한 특성들을 반영해야 한다. 즉, TAM 구조를 바탕으로 한 기존의 연구들에 의해 온라인 상거래의 수용을 설명할 수 있을지라도 더욱 높은 설명력을 확보하기 위해서는 인터넷의 고유한 특성을 반영할 필요가 있다.

기존의 온라인 상거래에 관련된 연구들에서 거래가 성립하기 위해 가장 필요하다고 제시

1 인터넷 쇼핑, 인터넷을 통한 서비스, 개인간 인터넷을 통한 거래 등 인터넷을 통해 행해지는 모든 상거래를 포괄하는 의미에서 온라인 상거래로 통칭함. 
된 요소는 신뢰이다. 온라인 상거래는 상거래 당사자들이 상대방을 직접 확인하지 못한 상 태에서 인터넷이라는 매체를 수단으로 하여 거래가 이루어지기 때문에 관련된 사람들간의 신뢰가 오프라인보다 더욱 중요하게 작용한다. 쇼핑에서 고려해야 할 또 하나의 요소는 개 인이 쇼핑상황에서 갖게 되는 감정이다. 사람은 행동을 할 때 감정의 영향을 받게 되며, 은 라인 쇼펑에서도 그 자체의 상황을 지각하면서 발생하는 감정이 영향을 미칠 수 있다. 즉, 감정은 온라인 상거래상의 행동에 대해서도 영향을 미칠 수 있다.

인터넷이 생활환경에 더욱 크게 영향올 미치게 됨에 따라 인터넷 쇼평을 비롯하여 온라 인 상거래를 설명하는 연구들이 계속 발표되고 있고, 앞으로도 관련 연구들이 계속 이어질 것이다. 그리고 인터넷 쇼핑몰을 포함하여 온라인 상거래의 성공요인과 성과를 좀 더 실질 적으로 연계 지올 수 있는 연구들은 마케팅 측면에서 더욱 필요하다(신기영, 추교완, 박동진 2001). 본 연구에서는 온라인 상거래의 수용을 설명하려는 목적에서 TAM 구조률 중심으로 인터넷을 통해 상거래가 이루어질 때 개인이 지각하는 특장을 반영하고자 하였다. 그리하여 TAM의 구조에 신뢰와 감정을 결합하여 확장하였다. 개별적으로 밝혀진 중요한 요인들을 동 합하는 과정을 통해 온라인 상거래의 성립에서 중요한 요인인 신뢰와 감정이 상거래 행동의 과정에 대해 미치는 영향을 이해할 수 있고 온라인 상거래의 수용과정을 더욱 포괄적으로 이해할 수 있을 것이다. 그리고 TAM에 신뢰와 감정을 결합하는 시도를 통해 온라인 상거래 의 수용 측면에서 소비자 행동을 연구함으로써 기존 연구들에 비해 온라인 쇼푕의 성공요인 을 파악하는데 전략의 유연성을 높일 것이다.

\section{2. 온라인 상거래의 수용에 대한 신뢰와 감정의 결합}

새로운 물질이나 아이디어, 즉 혁신이 확산되는 과정에는 사람들이 그 것을 받아들이는 과정, 즉 수용과정이 포함되어 있다. 혁신의 확산은 어느 개인이 새로운 것올 최초로 접한 후 완전히 받아들여 사용하는 단계에 이르기까지 거치는 과정인 수용과정을 통해서 이루어 진다. 인터넷은 정보통신 기술의 발전을 바탕으로 인간의 삶에 새롭게 추가된 환경이다. 그 러므로 인터넷관련 산업들은 혁신에 속한다. 사람들이 인터넷을 활용한 산업 중 하나인 온 라인 상거래를 수용하기 위해서는 온라인 상거래 자체에 두 가지 요소가 갖추어겨야 한다. 즉 사람들이 인터넷을 통해 상거래를 하는 것이 다른 방법에 비교해서 더욱 유익하다고 생 각해야 하고 사이트 자체를 쉅게 사용할 수 있다고 지각해야 한다.

혁신 대상을 수용하는데 있어서 유용성과 사용의 용이함에 대한 지각을 핵심개넘으로 하 는 모델은 TAM이다. TAM 검증 및 확장에 관련된 연구, TAM을 인터넷에 적용한 연구. TAM을 인터넷 쇼핑에 적용한 연구들을 정리하고, 여기에 덧붙여 온라인 상거래에서의 신뢰에 관한 연구, 상거래에서의 감정에 대한 연구들 정리하면 <표 1>과 같다.

온라인 TAM의 검증 및 확장에 관한 연구들은 계속되고 있으며, 인터넷이 발달함에 따라 최근에는 인터넷 및 인터넷 쇼팡의 수용을 설명하는데 TAM을 적용하려는 연구들도 많아지고 있다. 인터넷 쇼핑에 TAM을 적용하는 연구들은 외부변수를 인터넷 환경이나 시스템의 조건 과 같은 공급자 요소에서 파악하는데 치중하고 있다.

그렇지만 소비자 행동 및 지각차원에서 온라인 상거래에 대한 연구들도 제시되고 있다. 온라인 상거래에 관한 많은 연구들을 통해 중요하게 나타난 요인은 신뢰이다. 특히 인터넷 
이 가지는 익명성 때문에 인터넷 상에서의 거래 관계자들간의 신뢰는 온라인 상거래에서 매 우 중요한 요인으로 대두되고 있고, 다양한 연구들에서 신뢰의 중요성이 중명되고 있다.

<표 1> 기존 연구 정리

\begin{tabular}{|c|c|}
\hline 구분 & 내용 \\
\hline TAM 검증 & $\begin{array}{l}\text { TAM 구성개넘 측정척도 개발(Davis 1989), TAM과 TRA 모델 비교검증(Davis, } \\
\text { Bagozzi, and Warshaw 1989) TAM 검증(Davis and Venkatesh 1996), TAM 연구들의 } \\
\text { Meta 분석(Legris, Ingham, and Collerette 2002), 세 개의 국가에 } \\
\text { 기술수용모델의 검증(Straub, Keil, and Brenner 1997) }\end{array}$ \\
\hline TAM 확장 & $\begin{array}{l}\text { TAM의 이론적 확장(Venkatesh and Davis 2000), 지각된 사용 용이함의 } \\
\text { 선행요소 모델(Venkatesh and Davis 1996), 지각된 사용 용이함의 } \\
\text { 결정요소(Venkatesh 2000), 유용성 과 사용 용이함의 심리적 } \\
\text { 원천(Karahanna and Straub 1999), TTF(task-technology fit) 모델을 포함하는 } \\
\text { TAM 확장(Dishaw and Strong 1999), TAM 이론에서 심리학적 요인들의 } \\
\text { 역할(손달호 2001) }\end{array}$ \\
\hline TAM 적용 & $\begin{array}{l}\text { WWW의 작업에 대한 TAM 연구(Lederer et al 2000), 온라인 소비자 행동에 } \\
\text { TAM과 Flow 이론 적용(Koufaris 2002), 디지털 도서관에 대한 사용자 수용 } \\
\text { 결정요인(Hong et al. 2002), 인터넷의 수용요인 실증연구(박순창, 정경수, } \\
\text { 이재록 2000) }\end{array}$ \\
\hline $\begin{array}{l}\text { 인터넷 } \\
\text { 쇼핑에 } \\
\text { TAM 적용 }\end{array}$ & $\begin{array}{l}\text { E-Commerce 수용에 있어서 지각된 사용 용이함의 상대적 중요성(Gefen and } \\
\text { Straub 2000), 온라인 쇼퓡에서 신뢰와 TAM(Gefen, Karahannna, and Straub } \\
2003 \text { ), 온라인 쇼핑에서 정보제시 형태의 영향에 대한 TAM 적용(Chau, Au, } \\
\text { and Tam 2000), 인터넷 서점에 대한 연구(윤철호, 김상훈 2003) 인터넷 } \\
\text { 쇼핑몰 이용에 영향을 미치는 요인(신기영, 추교완, 박동진 2001), 국내 } \\
\text { 인터넷 뱅킹 이용자의 이용의도에 영향을 미치는 요인(이건창, 정남호, } \\
\text { 이종신 2002), 금융서비스 유동상의 혁신수용(제진훈, 박윤재, 김광용 2002) }\end{array}$ \\
\hline $\begin{array}{l}\text { 온라인 } \\
\text { 상거래 } \\
\text { 와 신뢰 }\end{array}$ & $\begin{array}{l}\text { E-Commerce에서 친숙성과 신뢰의 역할(Gefen 2000), Web의 비밀 무기로써 } \\
\text { E-Loyalty(Reichheld and Schefter 2000), 인터넷 성공에 영향을 주는 요인들 } \\
\text { 측정(Torkzadeh and Dhillon 2002), 인터넷 서점 이용자의 웹서비스 평가가 } \\
\text { 상표신뢰와 애호도에 대한 미치는 영향(김재휘, 한미영, 김현주 2002), } \\
\text { 인터넷 뱅킹의 서비스의 품질 결정 요인(이상윤, 박광태 2001), 인터넷 } \\
\text { 쇼푕몰의 수용도에 영향을 미치는 요인으로서의 신뢰(서건수 2001), 인터넷 } \\
\text { 뱅킹에서 고객이 인지하는 가치가 고객 충성도에 미치는 영향(김정수, } \\
\text { 김영걸 2002), 기업과 소비자간 전자상거래에서 소비자 신뢰형성(박철 } \\
2002 \text { ) }\end{array}$ \\
\hline $\begin{array}{l}\text { 온라인 상거 } \\
\text { 래와 감정 }\end{array}$ & $\begin{array}{l}\text { 인터넷 쇼핑몰의 특징과 감정적 반응과의 관계(서문식, 김상희 2002), } \\
\text { 인터넷 쇼핑상황에서 경험하는 소비자 감정(서문식, 김상희, 서용한 2002) }\end{array}$ \\
\hline
\end{tabular}


그리고 아직 온라인에서 관심을 많이 받지는 못하지만 소비자 행동에서 중요하게 대두되 는 또 하나의 요인은 감정이다. 예를 들어, 사람은 쇼평하는 상황에서 어떠한 감정을 지각하 게 되고 그 과정에서 긍정적 감정이 발생하면 쇼핑하는 가치 또는 유용성을 높게 지각할 수 있다. 그리고 쇼핑 상황에서 긍정적 감정을 지각한 쇼핑객은 그러한 긍정적 감정을 가지고 있다가 나중에 쇼핑 기회가 발생하면 해당 쇼평몰에서 쇼핑할 의도를 높게 가질 수 있다. 인터넷 쇼퐝에서도 그러한 상황이 적용될 수 있다(서문식과 김상희 2002).

기존의 연구들은 온라인 상거래의 수용을 설명하면서 중요한 요인들을 각기 강조하고 있 다. 그렇지만 온라인 상거래에서 중요하다고 밝혀진 요인들울 소비자행동 차원에서 체계적 으로 통합하고 확장하는 연구를 통해 온라인 상거래의 수용 행동을 정확하게 설명하고 포괄 적으로 이해할 수 있을 것이다.

\section{1 온라인 상거래 수용: 기술수용모델(TAM) 중심의 구조}

2.1 .1 온라인 상거래에서 유용성, 사용 용이함, 사용의도

기술수용모델(TAM, technology acceptance model)은 사람들이 작업장에서 혁신적인 애플 리케이션(application)을 사용하고자 할 때, 작업자가 이 새로운 애플리케이션을 수용하는 데 있어서 실제 사용과 외부변수들의 인과관계를 설명하려는 목적에서 제시된 모델이다 (Davis 1989). Davis는 TAM을 개발하면서 사용자의 수용을 결정하는 두 개의 구체적인 신념 변수로 지각된 유용성(perceived usefulness)과 지각된 사용의 용이함(perceived ease of use)을 개발하고 타당화 하였다. 그리고 TAM은 혁신적인 분야의 수용을 설명하려는 연구들 에서 다양하게 적용되었다. 많은 연구들을 통해 TAM은 혁신적인 시스템 사용의 약 $40 \%$ 를 예 측한다고 인정받고 있다(Legris, Ingham, and Collerette 2002). 그리고 TAM은 합리적 행동 모델(TRA, Theory of Reasoned Action)과 계흭된 행동 모델(TPB, Theory of Planned Behavior) 과 같은 대안 모델보다 설명력이 높게 나타났다(Davis, Bagozzi, and Warshaw 1989).

유용성과 사용의 용이함이라는 두 가지 신념을 중심 개념으로 하는 TAM의 구조는 인터넷 관련 분야의 수용을 설명하는데도 많이 적용되고 있으며, 높은 설명력과 에측력을 보이고 있다. 첫째, $\mathrm{TAM}$ 의 구조를 바탕으로 인터넷 및 인터넷 활용 사이트의 수용을 설명한 연구들 이 있다(Chau, Au, and Tam 2000; Hong et al. 2002; Lederer et al. 2000). 둘째, 인터넷 쇼 핑에 관한 연구에서도 TAM 구조가 적용되는데, 인터넷 쇼핑에서 유용성, 사용의 용이함, 사 용의도의 관계는 유의하게 나타났다(Gefen, Karahanna, and Strub 2003; Koufaris 2002; 신 기영, 추교완, 박동진 2001; 윤철호, 김상훈 2003). 셋째, 유용성과 사용의 용이함 이외의 다 른 변수들의 영향을 고려하더라도 TAM은 전자상거래(e-commerce)에 적용될 수 있었다(Gefen 2000; Koufaris 2002). 넷째, 인터넷 뱅킹과 같이 인터넷 콘텐츠률 통해 서비스률 제공하는 분야에 대한 연구들도 사용의도, 유용성, 사용의 용이함 관계에서 TAM의 구조를 증명하였다 (이건창, 정남호, 이종신 2002; 제진훈, 박윤재, 김광용 2002).

인터넷 관련 분야, 인터넷 쇼평, 기타 인터넷을 활용한 서비스 분야에 이르기까지 유용성, 사용의 용이함을 주요한 신념으로 본 TAM의 구조가 성립되고 있다. TAM과 이를 인터넷에 확 장한 연구들을 바탕으로 사람이 온라인 상거래를 수용함에 있어 유용성, 사용 용이함, 상거 래 의도의 관계를 나타낼 수 있다.

가설 1. 온라인 상거래 사이트(시스템)에 대한 유용성 지각은 사용의도에 정적으로 영향을 온라인 상거래 수용에 관한 통합적 확장: 기술수용모뎁에 대한 신뢰와 감정의 결합 61 
줄 것이다.

가설 2. 온라인 상거래 사이트(시스템)에 대한 사용의 용이함 지각은 사용의도에 정적으로 영향을 줄 것이다.

가설 3. 온라인 상거래에서 사이트(시스템)에 대한 사용의 용이함 지각은 사이트(시스템)의 유용성 지각에 정적으로 영향을 줄 것이다.

\section{1 .2 온라인 상거래에서 사용의도와 상거래 행동}

연구자들이 행동을 에측하고자 할 때 가장 우선적으로 고려하는 측정변수는 태도이다. TAM은 합리적 행동이론(TRA)을 바탕으로 모형화되었기 때문에 최초에 개념적으로 설명될 때 는 태도를 포함하였다. 그리하여 유용성과 사용의 용이함이 태도에 의해 매개되어 사용의도 에 영향을 주는 것으로 구조화되었다. 그렇지만 그 뒤의 실증적 연구결과 태도가 사용의도 에 대한 유용성의 효과를 완전히 매개하지 못했기 때문에 TAM 모델에서 태도가 제외되었다 (Davis 1989; Davis, Bagozzi, and Warshaw 1989; Davis and Venkatesh 1996). 그 후 태도를 제외하고 융용성과 사용의 용이함, 사용의도, 사용행동의 관계로 구조가 표시되었고, 이러한 관계가 TAM의 기본적인 구조가 되었다.

TAM에서는 행동의도와 행동을 구분하여 행동의도가 행동에 영향을 준다고 구조화되었고, 이러한 관계는 실증연구를 통해 증명되었다. 그런데 인터넷 수용에 관한 연구들은 의도와 행동 중 하나의 변수만 가지고 수용정도를 파악하는 경향이 있다. 비록 일부 연구들은 사용 의도와 사용행동 둘 다를 포함하였지만(예, 이건창, 정남호, 이종신 2002), 많은 연구들은 행 동을 측정하지 않고 사용의도만 측정하고 있다.

사람들의 온라인 상거래 수용을 정확히 파악하고 설명하기 위해서는 의도와 행동을 구분 하여 이 두 변수의 관계를 명확히 할 필요가 있다. 그리고 이렇게 온라인 상거래에서 의도 와 행동을 구분하여 관계를 파악하면 의도가 행동으로 전환되는 과정에서 영향을 주는 변수 를 찾는데도 도움을 줄 것이다. 기존 연구들을 바탕으로 온라인 상거래 의도와 행동의 관계 를 다음과 같이 나타낼 수 있다.

가설 4. 온라인 상거래 사이트(시스템)의 사용의도는 상거래 행동에 정적으로 영향을 줄 것 이다.

\section{2 온라인 상거래 수용에 대한 신뢰의 결합}

TAM은 혁신 기술의 수용을 유용하게 설명하고 있지만 설명력울 더욱 높이기 위해서는 인 간과 사희변화 과정을 포함하여 영향을 미칠 수 있는 변수들을 반영해야 한다(Legris, Ingham, and Collerette 2002). 특히 TAM이 기업체에서 애플리케이션을 수용하는 현상을 설 명하는 것을 목적으로 했다는 점에서 이 모델의 구조를 다른 분야에 적용할 때는 해당 분야 의 고유한 특성을 반영해야 설명력을 높일 수 있다. 인터넷 관련 분야의 경우에도 비록 많 은 연구들이 유용성과 사용 용이함에 의해 개인이 인터넷 관련 분야롤 수용한다고 설명하고 있지만, 온라인 상거래의 수용을 보다 정확히 설명하고 예측하기 위해서는 관련된 특성을 반영해야 한다.

기존의 온라인 상거래관련 연구들을 볼 때, 온라인 상거래에서 가장 먼저 고려해야 할 조 건은 거래에 관련된 사람들 그리고 거래 시스템에 대한 신뢰 형성이다. 온라인 상거래에서

\section{2 한국마케팅저녈 제 6 권 1호}


신뢰가 중요하게 고려되는 이유는 사람들이 인터넷을 통해 상거래를 하고자 할 때 상거래 업체가 해로운 기회주의적 행동을 하지 않을 것이라고 중명된 보증을 받을 수 없고, 온라인 상거래에 대한 효과적인 규제가 현실적으로 부족하기 때문이다(Gefen 2000; Reichheld and Schef ter 2000)

\section{2 .1 신뢰의 개념적 정리}

초기에 신뢰를 개념화할 때는 개인이 상대방에 대해 갖는 '기대'를 중심으로 파악되었다. 연구자들이 많이 인용하는 신뢰에 대한 초기의 정의를 보면, 신뢰는 "한 개인이 다른 사람 의 말에 의지할 수 있다는 일반화된 기대"(Rotter 1971), 또는 "한 개인이 다른 개인이나 집 단의 행동이 이타주의적이고 유익하다고 갖는 기대"로 정의된다(Frost, Stimpson, and Maughan 1978).

신뢰에 대한 연구가 확장되면서 '기대' 외에 '신뢰섬', '믿음(belief)' '안심의 느깜 (security feeling)' 둥과 같은 추상적인 개넘이 추가되어 신뢰는 다차원적인 성격으로 여겨 지게 되었다. 그리고 신뢰하는 편이 갖는 '취약성(vulnerability)'을 반영하는 연구자도 있 어 힘의 불균형까지 고려되는 개념으로 범위가 확장되었다. 구체적으로, 신뢰는 한 편이 교 환의 상대방이 신뢰성(reliability)과 고결함(integrity)을 갖고 있다고 확신할 때 존재한 다(Morgan and Hunt 1994). 신뢰는 어느 개인이 다른 사람의 선의(goodwil1)와 신뢰성을 평 가하는 것이며 다른 사람이 행하는 바람직한 행동의 가능성에 대한 개인의 믿음과 기대이다 (예, Wicks, Berman, Jones 1999). 또는 위험을 포함하는 교환 관계에서 한 개인이 다른 사 람에 대한 취약성을 반영하는 행동이다(예, Moorman, Zaltman, and Deshpande 1992). 그리고 신뢰는 결백함(probity), 공평함(equity), 신뢰성, 만족의 네 예측차원들과 관련된 것으로 간주되기도 하였고(Michel1, Reast, and Lynch 1998), 기업간 그리고 기업집단간의 관계에서 '정직(honesty)'과 '자비(benevolence)' 두 주요한 형태로 구분되기도 하였다 (Atuahene-Gima and $\mathrm{Li} 2002$ )

신뢰와 관런된 또 한가지 특징은 그 것에는 변화하는 성격이 있다는 점이다. 즉, 신뢰는 기대와 경험에 의해 발전하는 성향이 있다. 신뢰는 과거 경험과 이전의 상호작용으로부터 발전하고(Rempel et al. 1985), 경험을 통하여 발달한다(Raveld and Gronroos 1996).

Gefen, Karahanna, Strub(2003)은 여러 연구자들의 정의와 개념을 정리하여 신뢰를 다음의 네 차원으로 나타내었다. 첫째, 고결함, 자비심, 그리고 상대편의 능력에 대한 구체적인 믿 음들, 둘째, 상대편이 신뢰성이 있다는 일반적인 민음, 때때로 신뢰하고자 하는 의도 혹은 상대편의 행동에 취약할 수도 있는 또 다른 편의 기꺼움, 셋째, 상대편의 돌보는 반응에 대 한 확신과 안심의 느낌, 넷째, 위의 세 가지 요소들의 결합이다.

\section{2 .2 온라인 상거래에서 신뢰와 유용성}

온라인 상거래에서 신뢰가 중요하게 고려되는 이유는 거래의 위험과 불안 때문이다. 사람 들이 온라인 상거래를 할 때는 거래 당사자들이 서로 대면하지 않고 인터넷이라는 매체를 이용하기 때문에 위험과 불안을 경험한다(Koufaris 2002). 온라인 상거래에서 신뢰는 위험과 불안을 해소하는 역할을 하기도 한다.

실증연구들은 온라인 상거래에서 신뢰가 거래의 가치를 높여 온라인 상거래의 유용성을 높게 지각하도록 할 수 있을 보여주었다. 인터넷 쇼평몰을 대상으로 한 연구결과, 보증에 대 한 신뢰성이 지각된 위험과 지각된 품질에 영향을 미첬다(박유식, 한명희 2001). 다른 연구 
에서도 신뢰는 사용의 용이함으로부터 영향을 받으며 사용의 용이함이 유용성을 중가시키는 것보다 훨씬 많이 유용성을 높이는 효과가 있었다(Gefen, Karahanna, Strub 2003).

신뢰는 상표에 대해 가치를 부여하고 애호도를 형성하는데 중요한 역할올 하는데, 신뢰의 역할은 온라인 상거래에서도 적용될 수 있다. 신뢰(trust)는 상표와 소비자 관계를 형성하 여 상표자산의 한 부분이 된다(Ambler 1997). 신뢰는 소비자가 상표와 장기적인 관계를 유지 하려고 하는 욕망을 갖게 되는데 있어서 핵심이 되는 변수이다. 소비자는 특정 상표를 신뢰 함으로써 해당 상표가 자신의 기대를 충족시켜줄 것이라고 안심하는 느낌을 갖는다 (Delgado-Ballester and Munuera-Aleman 2000).

기존 연구들올 볼 때, 온라인 상거래에서 신뢰는 거래에서 발생하는 불안과 위험을 해소 하는 역할울 한다. 그리고 거래 상대방의 가치를 높이고 애호도를 형성하는데 영향을 준다. 이러한 신뢰의 영향들은 온라인 상거래에서 유용성을 높게 지각하는 결과를 가져온다.

가설 5. 온라인 상거래 관련자와 시스템에 대한 신뢰는 사이트(시스템)의 유용성 지각에 정 적으로 영향을 줄 것이다.

\subsection{3 온라인 상거래에서 신뢰와 사용의도}

온라인 상거래에서 신뢰는 사용의도와도 밀접한 관련이 있다. 온라인 상거래에서 신뢰의 핵심 개념은 거래과정과 관련한 믿음 또는 인터넷 행동의도의 결과를 나타내는 전자상거래 업체에 대한 일반적인 믿음으로 개념화될 수 있다(Gefen 2000). 전자상거래 업체에 관한 구 체적인 믿음들로써 높은 수준의 신뢰는 사용의도와 높은 수준으로 연계되었다(Reichheld and Schefter 2000).

다양한 실증연구들은 온라인 상거래에서 신뢰가 사용의도에 영향을 미친다는 것을 증명하 고 있다. 인터넷 쇼팽몰의 수용도에 중요한 영향을 미치는 요인들 중 신뢰성은 경제성 (economy), 편의성 (convenience), 신용성 (credibility), 위험정보(information risk)와 더불 어 인터넷 쇼핑몰의 수용도에 통계적으로 유의한 영향을 미쳤다(서건수 2001). 인터넷 서점 을 연구 결과, 전자상거래 환경에서 신뢰는 유용성과 함께 전자상점 수용에 중요한 영향을 미치는 요인으로 나타났다. 그리고 두 요인 중 신뢰가 전자상점의 수용에 더 높은 영향 요 인으로 나타났다(윤철호, 김상훈 2003). 인터넷 뱅킹의 경우에도 신뢰가 중요한 요인으로 제 시되었다. 예를 들면, 고객이 인지하는 가치 중 신뢰는 사용편이성, 홍미성(interest)과 함 께 고객의 인터넷 뱅킹에 대한 충성도에 유의한 영향을 미치는 것으로 나타났다(김정수, 김 영결 2002). 경험 있는 소비자들이 전자상거래 업체에 대한 신뢰는 유용성 및 사용 용이함 과 함께 구매 의도에 영향을 주었다. 이러한 결과는 인터넷 활동에서 신뢰가 필요하다는 이 전 연구의 결과들을 확증한 것이다(Gefen, Karahanna, and Strub 2003). 온라인 상거래에 관 련된 실증 연구들과 TAM을 적용한 연구들을 바탕으로 온라인 상거래에서 신뢰는 사용의도에 영향을 미치는 것을 판단할 수 있다.

가설 6. 온라인 상거래 관련자와 사이트(시스템)에 대한 신뢰는 사용의도에 정적으로 영향 을 줄 것이다.

\section{2 .4 온라인 상거래에서 신뢰와 행동}

거래관계의 행동적 측면에서 볼 때, 신뢰는 행동을 유발하는데 영향을 준다. 신뢰는 교환 
파트너의 신뢰성 수준과 파트너와 경험한 만족의 결과에 의해 파트너에 대해 형성하는 미래 의 기대를 포함한다(Ganesan 1994). 그리고 신뢰는 미래 성과의 예측된 수준의 결과를 일으 키는 만족한 경험 및 그 이후부터 동일한 파트너에게 의지하려는 함축된 기꺼움(willings) 을 가짐으로써 위험에 대처하는 행동으로 볼 수도 있다(McAllister 1995).

어느 소비자가 거래 상대방에 대해 신뢰를 형성하면, 그 소비자는 거래 상대방의 미래 활 동에 관해 확신 있게 예측할 수 있게 됨으로써 그 파트너에 대해 지각하는 위험이 감소된다 (Mayer, Davis, and Schoorman 1995; Morgan and Hunt 1994). 그리고 이렇게 위험이 감소되 면 소비자는 의도한 행동을 할 가능성도 높아진다. 인터넷 쇼핑에 관한 실증연구들의 결과 는 고객이 특정 쇼핑몰 업체를 신뢰하는 경우 애호도를 촏이는 결과를 보여주고 있다. 인터 넷 쇼핑에서 상표 신뢰는 웹서비스 경험에 대한 평가속성과 상표 애호도를 매개하여 영향을 미쳤다. 즉, 상표 신뢰는 상표 애호도가 형성되기 위한 선행조건으로 중요하였다(김재휘, 한 미영, 김현주 2002). 그리고 다른 연구에서도 신뢰는 소매업자들에 대해 애호도를 개발하는 기초가 된다는 사실을 밝혔다(Berry 1996; Morgan and Hunt 1994). 소비자 신뢰를 기대로 간 주한 Sirdeshmukh, Singh, and Sabol(2002)의 연구에서, 소비자가 서비스 제공자에게 의존적 이고 약속을 지켜야 할 경우 신뢰가 유지되었다. 상점에서의 신뢰는 개인간 결합 없이도 소 비자들이 형성하는 상점 애호도의 중요한 결정요소였다. 신뢰와 행동의 관계 그리고 인터넷 쇼핑에서 신뢰가 쇼핑몰 애호도에 미치는 영향을 고려할 때 온라인 상거래에서 신뢰는 온라 인 상거래 행동을 촉발하는데 영향을 줄 것으로 볼 수 있다.

가설 7. 온라인 상거래 관련자와 사이트(시스템)에 대한 신뢰는 상거래 행동에 정적으로 영 향올 줄 것이다.

\section{3 온라인 상거래 수용에 대한 감정의 결합}

온라인 상거래를 연구할 때 또 하나 고려해야 할 개념은 사람이 다른 대상 또는 특정한 상황에 대해 지각하는 감정이다. 사람의 감정은 개인간의 관계, 태도와 행동에서 중요하게 대두되는 개넘이다. 그리고 감정은 쇼핑에서도 중요한 역할을 하는 것으로 연구되고 있다. 기존의 많은 연구들은 대상 또는 상황의 정적인 감정이 제품 태도에 호의적인 편향을 일으 킬 수 있다는 것을 중명했다(예, Batra and Strayman 1990). 쇼평몰의 경헙에 의한 정적인(행 복한) 감정은 중립적인 기분보다 제품들에 대해 더 호의적인 태도를 보이도록 하는 경향도 있었다(Howard and Gengler 2001). 매장에서 경헙하는 일시적인 감정은 매장 환경과의 상호 작용에 의해 발생하는 것으로 쇼평객들의 행동에 매우 독톡한 영향을 미쳤다(Gardner 1985). 그 외에 쇼평몰에 대한 선호와 선택은 일시적인 감정상태와도 매우 밀접한 관련이 있었다 (Weinberg and Bottwald 1982). 오프라인 관련 연구와 인터넷 쇼핑 연구들을 보면, 온라인 상 거래가 이루어지는데 있어 거래에 관련된 사람들의 감정이 중요하게 작용할 수도 있음을 알 수 있다.

\subsection{1 감정의 개념적 정리}

감정과 관련된 개념은 affect, emotions, feeling, moods 둥 여러 용어들이 사용되고 있다. 그리고 이러한 용어들에 대한 연구자들의 정의도 다소 차이가 있고(성한기 김미련 1998), 이러한 관련 개넘들이 혼용되어 사용되는 경우도 많다(이학식, 임지훈 2002). 게다가 국내 
학자들이 연구를 하기 위해 영어의 개념을 우리나라 말로 옮겨 사웅할 때도 어느 연구자는 affect를 감정으로 하고 emotions를 정서로 표기하였으며(성한기 김미련 1998), 다른 연구 자는 affect를 정서로 표현하고 emotions를 감정으로 표기하였다(이학식, 임지혼 2002). 이 렇게 감정 개념이 혼용되어 사용된 이유는 감정이 정서와 느낌을 포함하는 복잡한 구성체로 간주되었기 때문이다(Holbrook and Batra 1987).

연구자들의 개념화를 빌려 affect, emotions, moods의 관계를 정리하면 다음과 같다. Affect는 균형 있는 느낌의 상태에 대한 일반적인 서술용어로 가장 많이 사용된다. Affect 는 감정상태의 일반적인 기술용어이며, emotions과 moods는 감정 상태의 특수한 예가 될 수 있다(성한기 김미련 1998). Emotions는 moods보다 더욱 강하며 특정자극에 관계되고 (Gardner 1985; Isen 1984), 충동적인 자극에 주의의 초점을 두도록 하기도 하고 지속적인 목 표 지향적 활동의 분열을 유도하기도 한다(Cohen and Areni 1991; Simon 1967). 그리고 moods 는 느낌 상태로 그 것의 원인이나 상태에 대한 영향에 의식적인 주의를 두지 않고 끌어내어 지고 유지될 수 있다(Cohen and Areni 1991).

그런데 혼용되는 추상적인 용어들을 임의로 정의하고 구분하는 것온 오히려 더욱 혼돈을 가져오고 내용 자체의 이해를 어렵게 할 수도 있으므로, 기존 연구자들은 감정을 포괄적인 개념으로 사용하는 방법을 취했다(이학식, 임지훈 2002). 예들 들면, Edell and Burke(1987) 그리고 Burke and Edell(1989)은 affect, emotions, moods를 구분하지 않았으며, Laverie et al.(1993)은 감정을 포괄적인 의미로 사용하였다. 본 연구에서는 기존 학자들의 개념화를 고려하면서 이해의 편의를 돕기 위해 affect를 가장 큰 의미의 감정으로 하고 emotions을 하위개념의 감정 또는 정서로 하였다. 그리고 영어의 affect와 emotions을 모두 감정으로 사용하였다.

감정에서 또 하나 논란은 감정의 차원에 관한 것이다. 먼저 감정올 단일 차원으로 보는 견해가 있다(Russel1 1980). 이러한 견해는 긍정적 감정과 부정적 감정이 부적인 상관관계를 갖는다고 본다(01iver 1993). 이와 다른 견해로 감정을 두 차원으로 보는 학자들도 있다 (Watson and Tellegen 1985). 그들은 긍정적 감정과 부정적 감정이 독립적이어서 상관이 전 혀 없다고 주장하였다(유창조, 현소은, 전중옥 1997; 이학식, 임지훈 2002). 기존 연구들을 보면, 온라인 상거래관련 감정이 긍정적 상태와 부정적 상태로 구분될 수 있다고 보는 것이 무난하다. 그렇지만 온라인 상거래에서 긍정적 감정과 함께 부정적 감정이 존재한다고 간주 하더라도, 만약 어면 사람이 특정의 온라인 상거래에 대해 강한 부정적 감정을 가진다면 온 라인 상거래를 하지 않으려고 할 것이다. 그렇기 때문에, 현재 온라인 상거래를 하고 있는 사람들은 긍정적 감정은 높지만 부정적 감정은 약할 것으로 가정할 수 있다. 본 연구에서는 온라인 상거래의 수용에서 사람들의 온라인 상거래 의도와 행동으로 보기 때문에 온라인 상 거래를 하고 있는 사람들의 긍정적 감정을 중심으로 영향 관계를 파악하였다.

태도를 중심으로 보면, 감정은 태도를 형성하는 하나의 요소로 간주되지만 감정은 포괄적 이고 광범위한 개념으로 태도형성 과정에서 영향을 주는 요소도 된다. 특히 쇼핑과 감정의 관계에 대한 연구들은 지각차원의 감정에 초점을 두었다. 사람은 어떠한 상황에서의 경험이 나 느낌에 의해 감정을 형성할 수도 있다. 이 것은 단순한 지각차원의 감정 혹은 일시적 감 정이다. 개인은 쇼푱하는 상황에서 긍정적 감정을 지각함에 따라 특정 인터넷 쇼핑 상황에 서 가치 또는 유용성을 높게 지각할 수 있다. 온라인 쇼핑자는 특정 인터넷 쇼핑몰에서 긍 정적 감정을 겅험함에 따라 추후에 쇼핑 기회가 발생하면 해당 쇼핑몰에서의 쇼핑의도가 높 아질 수 있다(Dawson, Bloch, and Ridgway 1990; Yoo, Park, and MacInnis 1995; 유창조 1996; 
유창조, 현소은, 전중옥 1997). 인터넷 쇼핑에서 감정이 태도에 영향올 주는 결과는 서문식 과 김상희(2002)의 연구에서 제시되었다.

\subsection{2 온라인 상거래에서 긍정적 감정과 유용성}

감정은 의사결정 과정에서 정보가 처리되는 방법에 영향을 미칠 수도 있고(Petty, Caccioppo, and Goldman 1981), 제품이나 상표를 선택하기 위해 정보가 기억에 저장되는 방 법에 영향을 미칠 수도 있다(Gorn 1982; Zajonc and Markus 1982). 또한 개인들은 상표들이 제 공하는 감정 혜택들올 이해하고 평가하는데 감정에 의한 지식을 사용한다(Ruth 2001). 이렇 게 감정은 사람들의 지각작용에 영향을 미치기 때문에 온라인 상거래의 가치판단에도 영향 을 미칠 수 있다. 그리고 그 결과로 특정 사이트를 통해서 특정 상대방과 실시하는 온라인 상거래의 유용성을 지각하는데도 영향을 미칠 수도 있다.

Hirschman and Holbrook(1982)에 의하면, 사람의 구매행동은 합리적이고 논리적인 사고 뿐만 아니라 감정적 동기에 의해서도 이루어질 수 있다. 그들은 사람들이 제품을 구매하는 자체와는 별개의 쇼썽과정에서 즐거움, 환타지와 같은 기뽄 감정을 경험하려는 목적에서 소 비행동을 한다고 하였다. 그런데 이렇게 상거래 자체의 유용성을 지각하도록 하는 캐락적 소비(hedonic consumption)가 온라인 상거래에서도 발생할 수 있느나는 점을 생각해야 한다. 온라인 쇼핑에 관한 실증 연구에서. 쇼평 즐거움과 같은 감정적인 경험은 소비자들을 유지 하는데 도움을 줄 수도 있었고, 웹 사이트에 대한 감정적인 반웅도 같은 호과를 가질 수 있 었다. 온라인 소비자들은 순수하게 실용적이지 않으며, 단지 쇼핑의 효능감에 가치를 두었다. 온라인 소비자들을 되돌아오도록 만들기 위해서는 온라인에서 소핑을 즐길 수 있는 것으로 도 충분하였다(Koufaris 2002). 결국 인터넷 쇼핑 환경을 보다 즐겁고 훙미롭게 만들고 소비 자의 여러 감각을 자극하면 소비자의 캐락적 구매 목적을 달성시킬 수 있으며 제품평가와 의사결정 과정에서 긍정적인 감정을 갖도록 유도할 수도 있다. 이와 같이 기존 연구들을 보 면, 온라인 상거래에 있어서 개인이 대상, 시스템, 환경 둥에 대해 갖는 긍정적 감정은 유용 성을 지각하는데 영향을 미칠 것으로 판단할 수 있다.

가설 8. 온라인 상거래에서 긍정적 감정은 유용성 지각에 정적으로 영향올 줄 것이다.

\subsection{3 온라인 상거래에서 긍정적 감정과 사용의도}

사람이 어떤 대상에 대해 정적인 감정을 갖거나 어떤 상황에서 좋은 기분을 느끼게 되면 호의적인 태도가 발생하며 행동을 하고자 하는 의도가 높아질 수 있다. 연구들에 의하면, 긍 정적인 감정은 제품 태도에 호의적인 편항을 일으킬 수 있었다(Batra and Strayman 1990; Edell and Burke 1987). 그리고 경험에 의한 정적인(행복한) 감정은 중립적인 기분보다 제품 들에 대해 더 호의적인 태도를 나타내도록 하는 경향이 있었다(Howard and Gengler 2001).

감정에 대한 실증 연구들은 감정이 소비자의 태도 혹은 의도에 영향을 미친다는 것을 보 여준다. Ruth(2001)의 연구에 의하면, 상표가 제품 범주와 연계되어 가치 있는 감징 혜택과 조화되는 정도는 감정 혜택 일치성에 의해 영향을 받았다. Howard and Gengler(2001)의 연구 에 의하면, 감정적 전염은 소비자들의 제품관련 태도에 긍정적 편향을 일으킬 수 있었다. 발 신자들이 행복하고 수신자들이 발신자들을 좋아할 때, 수신자의 감정은 발신자들의 행복한 감정으로 수렴되고, 정적인 태도 편향이 발생하였다. 오프라인에서 쇼핑을 할 때 감정의 영 향이 쇼핑 태도나 의도에 미치는 영향에 관한 연구들을 통해 온라인 상거래에서 감정의 영 
향을 추정할 수도 있다. 매장에서 경험하는 일시적인 감정은 쇼평객들의 행동에 매우 독특 한 영향을 미쳤고(Gardner 1985), 쇼핑몰에서의 일시적인 감정상태는 쇼핑몰의 선호 맟 선택 과 매우 밀접한 관련이 있었다(Weinberg and Bottwald 1982). 매장 내에서의 기분과 소비자 의 소핑경험의 질이 쇼핑의사에 유의한 영향을 미치기도 하였고(Swinyard 1993), 매장의 분 위기에 노출되어 갖게 되는 즐거움은 쇼평시의 쇼펑 금액, 쇼핑 시간 및 매장을 다시 방문 하고자 하는 의사에 호의적으로 영향을 미쳤다(Donovan and Rossiter 1982). 그리고 매장 내 에서의 감정적 반웅은 쇼펑하는 동안 뿐만 아니라 쇼핑한 후 일정시간이 경과한 후에도 매 장에 대한 평가와 재방문의사에 유의한 영향을 미쳤다(Dawson, Bloch, and Ridgway 1990; Yoo, Park, and Maclnnis 1995; 유창조 1996; 유창조, 현소은, 전중옥 1997).

인터넷 쇼핑몰을 대상으로 한 연구에서도 쇼핑에서 발생하는 감정적 요인이 해당 인터냇 쇼핑몰을 다시 방문하는데 영향을 주었다. 인터넷 쇼평에 대한 연구에서, 인지적 요인 외에 감정적 요인이 태도나 재방문 의도에 영향을 미치며, 감정적 요인은 인터넷 쇼핑몰 특징이 태도나 재방문 의도에 미치는 영향에 매개변수로도 작용하였다(서문식, 김상희 2002).

온라인 상거래에서 감정의 영향을 행동과 관련하여 고려해불 수도 있지만, 감정은 유용성 과 수용의도에 영향을 미치는 과정에서 상당 부분 반영된다. 사람이 어떠한 감정을 가지고 있는 경우에 그 감정에 지배되어 상거래 행동을 결정하는 것은 충동구매의 경우와 같이 정 상적인 상태에서는 극히 드물게 일어날 수 있는 경우이다. 충동구매는 제품에 대해 강하게 호의적인 감정이 발생되는 순간에 즉각적으로 이루어진다(Weinberg and Gottwald 1982). 그 리고 소비자가 충동구매를 하는 원인 중에 하나는 이 것이 불쾌한 기분을 벗어나기 위한 수 단으로 작용하며, 사람들은 구매를 통한 즉각적인 욕구충족으로 행복감을 느끼는 것으로 나 타났다(Gardner and Rook 1988).

결국, 긍정적 감정이 온라인 상거래 행동에 직접적으로 영향올 주는 측면도 생각해볼 수 있겠지만, 긍정적 감정이 유용성과 상거래 의도에 의해 매개되지 않고 상거래 행동을 지배 하는 경우는 예외적으로 발생하는 것으로 볼 수 있다. 온라인 상거래에서 긍정적 감정과 상 거래 의도의 관계만 가정하여 다음과 같이 나타낼 수 있다.

가설 9. 온라인 상거래에서 긍정적 감정은 사용의도에 정적으로 영향을 줄 것이다.

\subsection{4 온라인 상거래에서 긍정적 감정과 사용의 용이함}

어떤 사람이 온라인 상거래를 하고자 할 때, 이용할 사이트 흑은 시스템을 편리하게 생각 한다면 그는 마음이 편해질 것이고 안정감을 느낄 것이며 자신감도 가질 것이다. 이러한 개 인의 감정은 이용할 사이트 흑은 시스템에 대해 긍정적 감정을 갖도록 영향을 줄 수도 있다. 서문식, 김상희(2002)의 연구에서, 개인과 인터넷 쇼핑몰의 상호작용성은 긍정적 감정에 정 적으로 유의하게 영향을 주었는데, 이 때의 상호작용성은 소비자가 인터넷 쇼팡을 편리하게 지각하도록 하는 역할을 할 수도 있었다. 그리고 유창조, 현소은, 전중옥(1997)의 오프라인 매장의 특징과 쇼핑 감정에 관한 연구에서도 매장내의 편의 시설과 분위기 등은 쇼핑객의 감각적 활동에 대한 감정적 반웅에 주로 영향을 미치는 것으로 나타났다.

가설 10 . 온라인 상거래에서 사용 용이함 지각은 긍정적 감정에 정적으로 영향을 줄 것이 다. 


\section{4 온라인 상거래에서 신뢰와 감정의 관계}

믿음, 기대, 안심과 같이 신뢰를 설명하는 요소들을 볼 때, 신뢰는 인지적 과정에 의해 형 성된다고 볼 수 있다. 신뢰를 인지적인 요소로 보고, 인지와 감정간의 관계를 바탕으로 신뢰 와 감정의 관계를 추론할 수 있다.

인지와 감정간의 관계는 크게 두 가지의 서로 다른 견해가 있다. 첫째, 인지가 감정의 선 행요인으로 작용한다는 견해이다(Schachter and Singer 1962). 이러한 견해는 소비자행동 연 구자들이 인지 이후에 감정이 발생한다고 간주해 온 주장이다(Anand, Holbrook, and Stephens 1988).

둘째, 감정이 인지와는 독립적으로 발생할 수 있다는 견해이다(Zajonc 1980; Zajonc and Markus 1982). 이러한 견해에 의하면, 인지가 반드시 감정을 결정하는 것이 아나고 감정에서 인지로 향하는 방향도 있다. Zajonc(1980)는 인지와 감정을 합쳐서 매우 상호의존적인 존재 로 간주하기보다는 비교적 독립적인 하위 체계로 간주해야 한고 주장하였다. 그리고 Zajonc and Markus(1982)는 인지와 감정이 별도의 독립된 체계라는 독립성 가설을 제시하였다. 즉, 감정은 인지 없이도 생겨날 수 있으며 인간생활에 있어서 인지보다 감정이 더 중요한 역할 올 담당한다는 것이다. 다만, Zajonc and Markus(1982)의 독립성 주장은 감정이 인지와는 무 관하게 발생할 수 있다는 것이며, 모든 감정이 항상 인지로부터 영향을 전혀 받지 않는 것 은 아니다. 즉, 인지와 감정은 발생 자체에서는 개별적으로 발생할 수 있지만 서로간에 어느 정도 관련이 있을 수 있다.

인지와 감정의 사람의 사고작용이므로 인지와 감정은 서로 영향을 주는 양방향성이 있는 데(Izard 1992), 앞의 두 가지 주장을 바탕으로 인지와 감정의 영향관계를 보면, 인지가 감 정보다 먼저 작용한다고 보는 것이 일반적 견해임을 알 수 있다. 그러므로 개인이 온라인 상거래를 하는 과정에서 인지의 한 요소인 신뢰가 형성되면 그 신뢰감에 의헤 정적인 감정 이 발생할 수도 있다. 예를 들어, 인터넷 쇼평몰의 신뢰성과 고객서비스, 사이트, 제품은 감 정적 반웅에 의해 매개되어 쇼핑몰 태도나 재방문의도에 영향을 미쳤다(서문식, 김상희 2002). 기존 연구들올 종합하여 온라인 상거래의 수용에서 신뢰와 긍정적 감정은 밀접한 관 계를 맺고 영향을 주고받는데, 신뢰가 감정 보다 먼저 형성되어 감정에 영향을 주는 것으로 추정할 수 있다.

가설 11. 온라인 상거래에서 신뢰는 긍정적 감정에 정적으로 영향을 줄 것이다.

\section{5 온라인 상거래 수용의 통합적 확장}

기존 연구들을 바탕으로 유용성과 사용의 용이함을 중심으로 사람들의 온라인 상거래를 TAM으로 구조화 할 수 있다. 여기에 온라인 상거래에서 중요하다고 밝혀진 신뢰, 쇼핑에서 개인이 행동에 영향을 미치는 긍정적 감정을 결합하여 관계률 구조화하면 <그립 1>과 같다.

어떤 사람이 온라인 상거래를 하는 행동은 온라인 상거래 사이트(시스템)를 사용하고자 하는 의도에 의해 영향을 받는다. 그리고 온라인 상거래 사이트(시스템)를 사용하고자 하는 의도는 개인이 온라인 상거래를 함으로써 받을 수 있다고 지각하는 유용성에 의해 영향을 반으며, 개인이 온라인 상거래를 하기 위해 사이트 혹은 시스템을 사용하는 것이 용이하다 고 지각하는 정도에 의해 영향을 받는다. 또한 개인이 특정 사이트 혹은 시스템을 사용하는 
것이 섭다고 지각하면 할수록 그 사람은 그 만큼 노력과 시간을 적게 투입할 것으로 생각하 기 때문에 온라인 상거래의 유옹성도 높게 지각하게 된다.

어떤 사람이 온라인 상거래를 하고자 할 때 거래 상대방에 대한 신뢰와 시스템에 대한 신뢰가 높으면 거래 상대방이 자신을 속여서 자신이 입게 될 손해의 가능성을 그 만큼 적게 생각하게 되고, 해당 온라인 상거래 자체에 대한 유용성을 높게 지각할 것이다. 그리고 거래 상황에서 믿음과 기대를 기초로 한 신뢰가 있어야 거래 관련자들이 온라인 상거래를 하고자 하는 의도가 생길 수 있다. 즉, 온라인 상거래에서 신뢰는 상거래 의도에 영향을 준다. 또한 어떤 사람이 거래 상대방과 시스템을 높게 신뢰하게 되면 거래를 할 때 발생할 수 있는 망 설임이나 갈둥이 줄어들고 행동 자체가 촉발될 가능성도 높아진다.

쇼푕관련 연구들에서 감정은 쇼핑 행동에 영향을 주는 주요한 요인으로 나타났다. 인터넷 소핑을 포함한 온라인 상거래에서도 감정의 영향이 고려되어야 한다. 개인이 특정 인터넷 사이트에 대해 좋은 감정을 가지고 있거나 정적인 감정이 발생하는 상황이 되면 해당 사이 트를 통해 온라인 상거래를 하는 것 자체의 유용성을 높게 지각할 것이다. 그리고 어떤 사 람이 특정 사이트에 대해 긍정적인 감정을 가지고 있으면 그 사이트를 통해 상거래를 할 의 도도 높아질 것이다. 또한 만약 누군가가 사용하고자 하는 시스템을 잘 알고 뉩게 사용할 수 있으면, 그는 자신감을 갖게 되고 편안함과 같은 긍정적인 감정을 느낄 것이다. 그러므로 온라인 상거래에서 감정은 사용의 용이함에 의해 영향을 받을 수 있다.

신뢰는 거래 상대방 및 시스템에 대한 믿음과 기대에 의해 발생하는 것이기 때문에 인지 적인 요소에 해당한다. 사람의 감정은 인지적 차원과 다른 또 하나의 정신적 요소이다. 인지 적 요소인 신념과 감정은 발생 자체를 독립적으로 볼 수는 있지만 서로간의 영향관계를 보 면, 인지적 작용인 신뢰가 감정에 영향을 미칠 가능성이 반대의 경우보다 높다 되면 이러한 감정이 신뢰를 형성하는데 정적으로 영향을 미칠 것이다.

<그림 1> 온라인 상거래 수용 구조

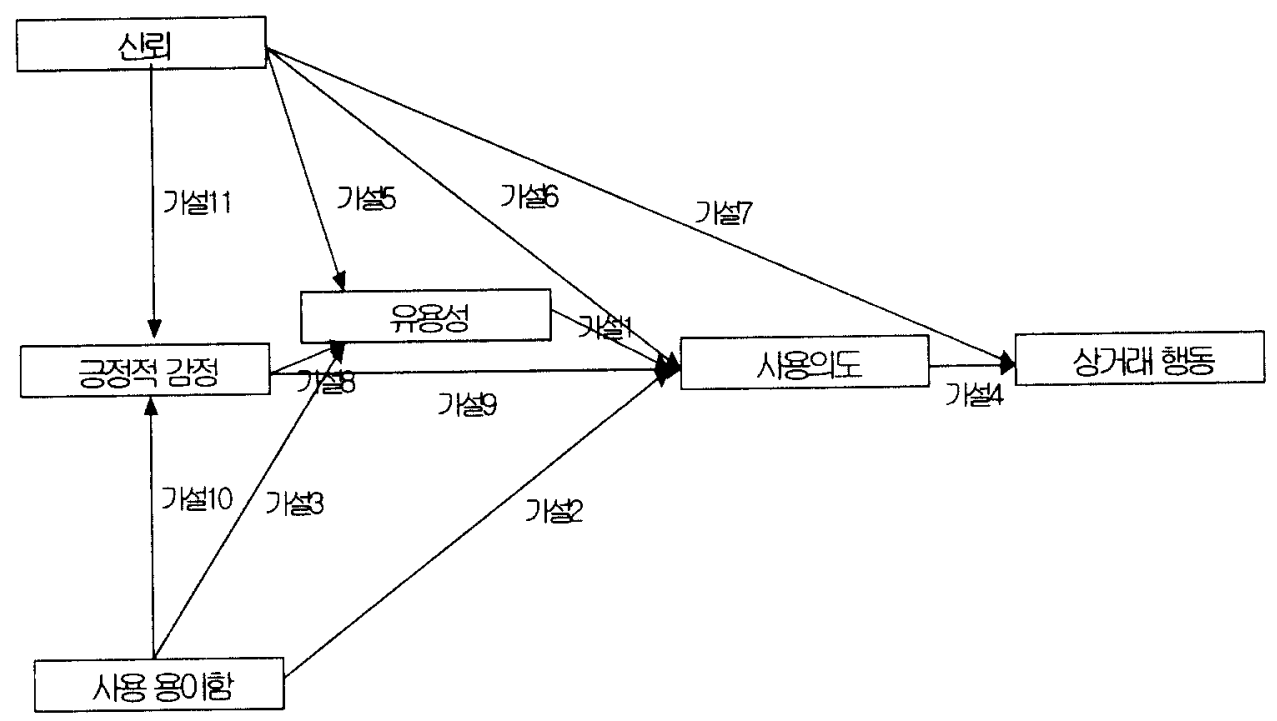




\section{3. 실중연구}

\section{1 연구방법}

\section{1 .1 문항선정}

이론 연구에서 제시된 온라인 상거래 수용에 대한 모델을 확증하고 가설올 검증하기 위해, 개인 소비자들의 온라인 상거래 행동관련 변수들을 측정하였다. 실증연구에서는 설문조사 방식이 적용되었다. 기존의 TAM관련 연구. 인터넷 수용에 관한 연구, 전자상거래 수용에 관한 연구, 신뢰에 관한 연구, 쇼핑에서 감정의 영향에 관한 연구들을 바탕으로 1 차로 설문 문항을 도출하였다. 온라인 상거래 의도를 묻는 문항은 Gefen, Karahanna, and Straub(2003), Venkatesh and Davis(2000)의 연구를 토대로 작성하였다. 사용의 용이함을 묻는 문항은 Gefen, Karahanna, and Straub(2003)의 연구를 바탕으로 작성하였다. 유용성을 묻는 문항은 Gefen, Karahanna, and Straub(2003), 이건항, 정남호(2000)의 연구에 근거하여 작성하였다. 신뢰를 묻는 문항은 Gefen, Karahanna, and Straub(2003), 서건수(2001)의 연구를 토대로 작성하였다. 긍정적 감정을 묻는 문항은 서문식, 김상회(2002), 유창조, 현소은, 전중옥(1997)의 연구문항을 활용하였다. 행동을 묻는 문항은 이건창, 정남호, 이종신(2002)의 연구에서 사용된 문항을 적용하였다.

설문에서 행동을 묻는 질문 2 개를 제외하고 각 문항은 7 점 척도로 구성하여 “(1) 전혀 그렇지 않다 (4) 그저 그렇다 (7) 아주 그렇다"로 하였다. 그리고 온라인 상거래 행동을 측정하는 질문은 한달 동안의 "인터넷 쇼핑몰 방문, 인터넷 쇼핑몰 이용" 두 문항으로 하였다. 1 차로 개발한 설문지를 가지고 서울소재 1 개 대학의 MBA과정 대학원생들에게 사전 조사를 하여 설문지를 수정한 다음, 31 개 문항으로 설문지를 완성하였다. 완성된 설문지는 상거래 의도 3 개 문항, 사용 용이함 5 개 문항, 유용성 7 개 문항, 신뢰 8 개 문항, 긍정적 감정 6 개 문항, 행동 2 개 문항으로 구성되었다. <표 2>의 문항선정에는 31 개 문항이 제시되어 있다.

<표 2> 문항선정

\begin{tabular}{|c|c|c|c|c|}
\hline 구분 & 문항 & 근거 & 제거 후 & 선정 \\
\hline IU & 사용의도 & & 0.641 & 0.680 \\
\hline IU1 & $\begin{array}{l}\text { 나는 이 사이트를 이용하기 위해 개인정보를 } \\
\text { 제공한다. }\end{array}$ & Gefen, & 0.460 & \\
\hline IU2 & $\begin{array}{l}\text { 내가 필요한 것을 더 잘 제공받기 위해 이 } \\
\text { 사이트가 요구하는 정보롤 제공할 가능성이 높다. }\end{array}$ & $\begin{array}{l}\text { Kar ahanna, and } \\
\text { Straub(2003) }\end{array}$ & 0.680 & 제거 \\
\hline IU3 & 나는 이 사이트를 이용할 의사가 있다. & $\begin{array}{l}\text { Venkatesh and } \\
\text { Davis }(2000)\end{array}$ & 0.484 & \\
\hline EOU & 사용의 용이함 & & 0.738 & 0.738 \\
\hline EOU1 & 이 사이트를 사용하기는 췁다. & Gefen, & 0.676 & \\
\hline EOU2 & 이 사이트는 쉽게 익숙해질 수 있다. & Karahanna, and & 0.671 & \\
\hline EOU3 & 이 사이트를 운용하는 방법은 쉅게 배울 수 있다. & Straub (2003) & 0.717 & \\
\hline
\end{tabular}




\begin{tabular}{|c|c|c|c|c|}
\hline EOU4 & 이 사이트는 유연성 있게 상호작용한다. & & 0.713 & \\
\hline EOU5 & $\begin{array}{l}\text { 이 사이트와의 상호작용은 명확하고 이해할 수 } \\
\text { 있다. }\end{array}$ & & 0.685 & \\
\hline U & 유용성 & & 0.875 & 0.876 \\
\hline 01 & $\begin{array}{l}\text { 이 사이트는 상품을 탐색하고 구매하는데 } \\
\text { 유용하다. }\end{array}$ & & 0.865 & \\
\hline U2 & $\begin{array}{l}\text { 이 사이트는 상품을 탐색하고 구매하는 나의 } \\
\text { 성과를 높여준다. }\end{array}$ & & 0.854 & \\
\hline U3 & $\begin{array}{l}\text { 이 사이트는 상품을 빠르게 탐색하고 구매할 수 } \\
\text { 있도록 해준다. }\end{array}$ & Gefen, & 0.851 & \\
\hline U4 & $\begin{array}{l}\text { 이 사이트는 상품을 탐색하고 구매하는 나의 } \\
\text { 효과를 높여준다. }\end{array}$ & Straub $(2003)$ & 0.853 & \\
\hline $\mathrm{U5}$ & $\begin{array}{l}\text { 이 사이트는 상품을 탐색하고 구매하는 것을 더욱 } \\
\text { 쉅게 해준다. }\end{array}$ & & 0.845 & \\
\hline U6 & $\begin{array}{l}\text { 이 사이트는 상품을 탐색하고 구매하는데 있어서 } \\
\text { 나의 생산성을 높여준다. }\end{array}$ & & 0.856 & \\
\hline U77 & 이 사이트는 다른 사이트보다 우수하다. & $\begin{array}{l}\text { 이건창, } \\
\text { 정남호 }(2000)\end{array}$ & 0.876 & 제거 \\
\hline $\mathrm{T}$ & 신뢰 & & 0.885 & 0.885 \\
\hline $\mathrm{T} 1$ & 나는 이 사이트가 정직하다는 것을 안다. & \multirow{7}{*}{$\begin{array}{l}\text { Gefen, } \\
\text { Karahanna, and } \\
\text { Straub(2003) }\end{array}$} & 0.866 & \\
\hline $\mathrm{T} 2$ & 나는 이 사이트가 고객들을 배려한다는 것을 안다. & & 0.866 & \\
\hline T3 & 나는 이 사이트가 기회주의적이지 않음을 안다. & & 0.868 & \\
\hline T4 & 나는 이 사이트가 좋은 서비스를 제공하는 것을 안다. & & 0.870 & \\
\hline T5 & 나는 이 사이트의 사용결과를 예상할 수 있다. & & 0.882 & \\
\hline T6 & 나는 이 사이트를 신뢰할만하다는 것을 안다. & & 0.860 & \\
\hline $\mathrm{T7}$ & 나는 이 사이트가 관련 시장을 잘 알고 있음을 안다. & & 0.882 & \\
\hline T8 & 나는 이 사이트의 운영자를 신뢰할 수 있다. & 서건수 $(2001)$ & 0.867 & \\
\hline $\mathrm{PE}$ & 긍정적 감정 & & 0.901 & 0.901 \\
\hline PE1 & 이 사이트를 사용할 때, 나는 즐거움을 느낀다. & \multirow{5}{*}{$\begin{array}{l}\text { 서문식, } \\
\text { 김상희 }(2002)\end{array}$} & 0.893 & \\
\hline PE2 & 이 사이트를 사용할 때, 나는 성춰감을 느낀다. & & 0.883 & \\
\hline PE3 & 이 사이트를 사용할 때, 나는 행복감을 느낀다. & & 0.873 & \\
\hline PE4 & 이 사이트를 사용할 때, 나는 편안함을 느낀다. & & 0.876 & \\
\hline PE5 & 이 사이트를 사용할 때, 나는 충족감을 느낀다. & & 0.880 & \\
\hline PE6 & 이 사이트를 사용할 때, 나는 자신감을 느낀다. & $\begin{array}{l}\text { 유창조, 현소은, } \\
\text { 전중옥 (1997) }\end{array}$ & 0.800 & \\
\hline $\mathrm{EC}$ & 상거래 행동 & & 0.329 & \\
\hline $\mathrm{EC1}$ & 한 달에 몇 번 정도 이 사이트롤 방문하십니까? & \multirow{2}{*}{$\begin{array}{l}\text { 이건창, 정남호, } \\
\text { 이종신 (2002) }\end{array}$} & & 제거 \\
\hline $\mathrm{EC2}$ & $\begin{array}{l}\text { 한 달에 몇 번 정도 이 사이트에서 서비스를 } \\
\text { 이용하십니까? }\end{array}$ & & & \\
\hline
\end{tabular}




\section{1 .2 조사실시}

서울소재 1 개 대학, 경기소재 1 개 대학, 충남소재 1 개 대학에서 경영학관련 수업을 수강하는 대학생과 대학원생들올 대상으로 설문조사를 실시하였다. 실시 시기는 2003년 9 월중이었다. 정규 수업시간에 수업을 시작하기 전에 조사를 하였는데, 조사시간은 약 10 분 정도 소요되었다. 설문조사를 실시할 때는 수업에 참석한 모든 학생들이 설문지에 응답하도록 하였다. 설문지를 구성할 때, 설문지의 맨 처음 부분에 웅답자가 인터넷 쇼핑 경험의 유.무를 표시하도록 하고, 인터넷 쇼평 경험이 있는 경우에는 구매한 인터넷 쇼평몰이 기억나는지 표시하도록 한 뒤, 웅답자들이 쇼핑몰의 이름올 적도록 하였다. 그리고 설문 웅답자들의 집중력과 성실도를 높이기 위해 수업에 참여한 학생들이 모두 설문지에 웅답을 하도록 하고, 인터넷 쇼핑 경험자 중 자신이 구매한 쇼핑몰을 기억하는 웅답자의 설문지만 분석에 사용하였다. 전체 설문지 310 개 중 부적합한 응답자와 불량 웅답자의 설문지 81 개를 제외하고 229 개의 설문지를 분석하였다. 조사 문항이 31 개이므로 229 개의 설문지는 구조방정식모델의 적절한 적용 기준인 문항대비 웅답자 5 배 이상의 요건을 충족시켰다.

응답자 중 남자는 107 명이고 여자는 122 명이었다. 대학생과 대확원생들을 조사 대상으로 하였기 때문에 평균 연령은 24.25세로 젋은 편이었다. 가장 적은 나이의 웅답자는 18세였고 가장 많은 나이의 웅답자는 54세였다. 웅답자가 가장 많은 연령은 20세로 37명(16.2\%)이었다.

\section{2 실증분석}

\section{2 .1 자료분석}

자료분석에서는 먼저 측정모델을 개발하고, 그 다음 구조방정식 모델을 적용하였다. 우선 구성 개념들의 신뢰도를 측정하여 측정모델을 확정하였다. Cronbach's a 로 신뢰도를 측정하여 대상 항목의 신뢰도를 떨어뜨리는 문항을 제거하였다. 상거래 의도에서 1개 문항, 유용성에서 1개 문항을 제거하였다. 그리고 상거래 행동을 측정하는 두 항목의 Cronbach's $\mathrm{a}$ 가 0.329 로 나타나 상거래 행동과 직접 관련이 있는 “사이트 이옹” 을 측정항목으로 선정하고 상거래가 발생하기 전 단계에 해당하는 “사이트 방문" 항목을 제거하였다. 그 외의 다른 예측변수 중에서는 상거래 의도가 0.641 로 나온 것만 제외하면 나머지 변수들은 Cronbach's a 가 0.7 이상이었다. 상거래 의도는 신뢰성이 있다고 받아들여지는 일반적인 기준인 0.7 보다 낮은데(Hair et al $1998 \mathrm{p118}$ ), 측정 문항 세 개 중 하나를 제거하더라도 Cronbach's $a$ 는 0.680 으로 0.7 다소 낮았다. Cronbach's $a$ 는 0.6 이상이면 수용할만한 수준으로 볼 수도 있지만(양희동, 강소라 2001), 이렇게 신뢰도가 낮으면 해석에서 문제의 소지가 있기 때문에 연구결과를 해석할 때 신중하게 할 필요가 있다(서건수 2001). 그리고 확인적 요인분석(CFA)을 통해 구성 개념의 신뢰도를 측정하였는데, <표 3>의 결과에서 보는 것과 같이 모든 요인에서 신뢰계수가 0.7 이상을 나타내어 일반적 기준인 0.6 을 초과하고 있고(임종원 $1996 \mathrm{p357}$ ), 평균분산추출(AVE, average variance extracted)에서도 신뢰도 기준인 0.5 이상으로 나타났다(배병렬 $2002 \mathrm{p152}$ ).

두 번쩨로 측정모델의 타당도를 검사하였다. <표 3> 확인적 요인분석 결과에서 보는 바와 같이, 사용의도(IU), 사용의 용이합(EU), 유용성(U), 신뢰 $(\mathrm{T})$, 긍정적 감정(PE), 상거래 행동 $(\mathrm{EC})$ 에 대해 28 개 문항을 확인적 요인분석한 결과 모두 $\mathrm{t}$-값이 2.0 보다 크게 나타나 집중타당도가 입증되었다(Joreskog and Sorbom 1989; 양희동, 강소라 2002), 그리고 판별 
타당도의 충족여부를 검토하기 위하여 $\mathrm{AVE}$ 가 구성개념간 상관계수의 제곱 값보다 높은지 확인하였다. <표 4> 구성개념간 상관관계 행렬에서 사용의 용이함과 유용성간의 상관이 0.719 로 가장 크고 이 값을 제곱하면 0.517 로 사용 용이함의 $\mathrm{AVE}(0.507)$ 보다 약간 높게 나왔지만 비숫한 수준이었다. 그리고 각 문항의 의미를 검토한 바, 각 변수에 대해 내용 타당도의 관점에서 문항을 제거할 수 없어서 문항들을 제거하는 것을 멈추었다.

확인적 요인분석의 결과를 보면 대체로 적용 가능한 적합도를 나타내지만, 일부는 적합도 기준보다 약간 낮게 나타나는 것을 알 수 있다. 자유도 314 에 $\times 2$ 는 406.47 을 나타내어 자유도에 대한 $\times 2$ 의 비율이 $1: 3$ 이하로 나타났다. CFI 는 0.96 으로 양호한 기준인 0.9 보다 높았고, RMSR 0.079 나타나 0.08보다 낮았다. 그렇지만 GFI 0.89 , AGFI 0.85 이고 NFI 0.88 로 나타나 양호한 기준인 0.9 보다 약간 낮게 나타났다.

최종적으로 선택한 28 개를 분석에서 사용할 문항으로 선택하였다. 변수별로 보면, 상거래 의도 2 개 문항, 사용 용이함 5 개 문항, 유용성 6 개 문항, 신뢰 8 개 문항, 긍정적 감정 6 개 문항, 상거래 행동 1 개 문항이었다.

<표 3> 확인적 요인분석 결과

\begin{tabular}{|c|c|c|c|c|c|}
\hline 요인 & 설문항목 & 추정치 & $t$-값 & 신뢰계수 & AVE \\
\hline \multirow{2}{*}{ 사용의도(IU) } & 1 & 0.71 & 6.92 & \multirow{2}{*}{0.748} & \multirow{2}{*}{0.808} \\
\hline & 2 & 1.07 & 9.82 & & \\
\hline \multirow{5}{*}{ 사용의 용이함(EOU) } & 1 & 0.80 & 11.27 & \multirow{5}{*}{0.726} & \multirow{5}{*}{0.507} \\
\hline & 2 & 0.73 & 9.96 & & \\
\hline & 3 & 0.64 & 6.80 & & \\
\hline & 4 & 0.41 & 5.65 & & \\
\hline & 5 & 0.48 & 6.28 & & \\
\hline \multirow{5}{*}{ 유용성(U) } & 1 & 0.72 & 11.63 & \multirow{6}{*}{0.893} & \multirow{6}{*}{0.728} \\
\hline & 2 & 0.86 & 13.37 & & \\
\hline & 3 & 0.76 & 12.23 & & \\
\hline & 4 & 0.75 & 12.73 & & \\
\hline & 5 & 0.81 & 13.03 & & \\
\hline & 6 & 0.73 & 9.93 & & \\
\hline \multirow{8}{*}{ 신뢰(T) } & 1 & 0.94 & 13.22 & \multirow{8}{*}{0.910} & \multirow{8}{*}{0.688} \\
\hline & 2 & 0.91 & 12.68 & & \\
\hline & 3 & 0.82 & 11.97 & & \\
\hline & 4 & 0.72 & 12.31 & & \\
\hline & 5 & 0.60 & 8.16 & & \\
\hline & 6 & 0.83 & 13.69 & & \\
\hline & 7 & 0.63 & 8.36 & & \\
\hline & 8 & 0.80 & 11.35 & & \\
\hline \multirow[t]{2}{*}{ 긍정적 감정 $(\mathrm{PE})$} & 1 & 0.69 & 12.09 & \multirow[t]{2}{*}{0.934} & \multirow[t]{2}{*}{0.828} \\
\hline & 2 & 0.88 & 13.38 & & \\
\hline
\end{tabular}




\begin{tabular}{|c|c|c|c|c|}
\hline & 3 & 0.98 & 15.44 & \\
\hline & 4 & 0.93 & 15.20 & \\
\hline & 5 & 0.88 & 13.91 & \\
\hline & 6 & 0.78 & 10.93 & \\
\hline 상거래 행동(EC) & 1 & 4.19 & 21.35 & 1.000 \\
\hline
\end{tabular}

<표 4>구성개념간 상관관계 행렬

\begin{tabular}{|c|c|c|c|c|c|c|}
\hline & 사용의도 & 사용 용이함 & 유용성 & 신뢰 & 긍정적 감정 & 상거래행동 \\
\hline 사용의도 & 1.000 & & & & & \\
\hline 사용 용이함 & 0.526 & 1.000 & & & & \\
\hline 유용성 & 0.372 & 0.719 & 1.000 & & & \\
\hline 신뢰 & 0.418 & 0.584 & 0.569 & 1.000 & & \\
\hline 긍정적 감정 & 0.337 & 0.418 & 0.475 & 0.463 & 1.000 & \\
\hline 상거래 행동 & 0.016 & 0.137 & -0.038 & -0.005 & 0.101 & 1.000 \\
\hline
\end{tabular}

기술적 분석에 의하면, 사용의도는 평균 5.406 으로 가장 높았고, 그 다음은 유용성으로 평균 5.218이었다. 반면, 긍정적 감정은 4.526 으로 가장 낮았고, 그 다음이 신뢰도로 평균 4.776 이었다. 긍정적 감정과 신뢰는 보통보다 약간 높은 수준이었다.

온라인 상거래 행동은 월 평균 2.3 희였는데, 표준편차는 4.19로 매우 크게 나타났다. 개인들의 온라인 상거래 행동에서 차이가 매우 큼을 알 수 있다. 이러한 결과는 온라인 상거래 행동의 측정에 문제가 있을 가능성을 나타낸다. 특히 온라인 상거래를 실시하고 있는 상황에서 상거래 행동 자체를 측정한 것이 아니므로 측정의 문제가 있을 가능성이 높다. 또한 표본 대상이 학생들이었기 때문에 온라인 상거래의 빈도가 적고 개인 차이가 클 수 있다. 각 구성개념의 평균과 표준편차는<표 $5>$ 의 기술통계 자로에 제시되어 있다.

<표 5> 기술통계 자료

\begin{tabular}{|l|c|c|}
\hline \multicolumn{1}{|c|}{ 구성개념 } & 평균 & 표준편차 \\
\hline 사용의도(IU) & 5.406 & 0.044 \\
\hline 사용의 용이함(EU) & 5.141 & 0.335 \\
\hline 유용성 (U) & 5.218 & 0.211 \\
\hline 신쾨 $(\mathrm{T})$ & 4.776 & 0.280 \\
\hline 긍정적 감정(PE) & 4.526 & 0.260 \\
\hline 상거래 행동(EC)* & 2.30 & 4.192 \\
\hline *은 단일항목 측정 & & \\
\hline
\end{tabular}




\section{2 .2 모델 비교}

제안모델의 적합도를 검증하고 대안모델과 비교하였다. 이 과정은 정제된 측정 모델에 대해 구조방정식 모델들을 비교하고 검토하는 것이다. 제안모델의 적합도 지수들은 대체로 받아들일 만한 수준 내에 있었다. 자유도와 $\times 2$ 는 $1: 1.312$ 의 비율로 $(x 2317=415.82) 3$ 배수 이내였다. CFI는 0.96 으로 양호한 기준인 0.9 이상이었고, RMSR는 0.098 로 0.08 보다 약간 높았으며, RMSEA $=0.037$ 로 0.08 기준이하 였다. 그렇지만 $\mathrm{GFI}$ 는 $0.88, \mathrm{AGFI}$ 는 $0.85, \mathrm{NFI}=0.87$ 로 0.9 기준보다 약간 낮았다.

제안 모델을 대안 모델들과 비교하였다. 대안모델 1 은 긍정적 감정이 쇼핑의도를 결정하는 태도의 유일한 구성요소가 된다고 간주한 것이다. 이 견해는 태도를 구성하는 인지적 요소인 유용성과 사용의 용이함이 정서적 태도인 감정에 영향을 미치고, 이 감정이 행동의도에 영향을 미친다고 보는 단일차원 견해를 바탕으로 구성한 것이다(양회동, 강소라 2001). 대안모델 2는 신뢰와 긍정적 감정의 관계를 별개로 보아 이 두 요소가 관련성이 없다고 보는 구조이다. 즉 제안모델에서 신뢰와 긍정적 감정이 서로 영향을 미치지 않는 다고 보는 것이다. 자유도와 $\times 2$ 롤 보면, 세 개의 모델 모두 1:3이하의 비율을 나타내 양호하였다. 구체적으로 보면, 제안모델(317:415.82)이 대안모델 1(320:452.12)과 대안모델 2 (318:430.05)보다 우수하였다. AIC 기준으로 보아도 재안 모델이 593.82로 대안모델 1(624.12)과 대안모델 2(606.50)보다 우수하였다. 적합도 검정의 다른 항목들을 보면, 제안모델이 대안모델들 보다 약간 낫거나 같은 수준이었다. 결국 제안모델이 다른 두 대안모델보다 우수하다고 볼 수 있다. <표 6>는 세 모델의 적합도 검정 결과를 보여준다.

<표 6>적합도 검정 결과

\begin{tabular}{|c|c|c|c|c|}
\hline 항목 & 제안모델 & 대안모델 1 & 대안모델2 & 판단 \\
\hline$x^{2}$ & 415.82 & 452.12 & 430.05 & $\mathrm{x} 2$ 과 $\mathrm{df}$ 근접 \\
\hline 자유도(df) & 317 & 320 & 318 & \\
\hline 유의수준(P Value) & 0.00016 & 0.00 & 0.00 & 0.05 이상 (비유의적 좋음) \\
\hline 기초부합지수(GFI) & 0.88 & 0.88 & 0.88 & 0.90 이상 \\
\hline 원소평균제 곱잔차(RMSR) & 0.098 & 0.11 & 0.10 & $0.05-0.08$ 이하 \\
\hline $\begin{array}{l}\text { 근사원 소평균 제곱잔차 } \\
\text { (RMSEA) }\end{array}$ & 0.037 & 0.043 & 0.039 & $0.05-0.08$ (0.08 이하) \\
\hline 비표준부합지수(NNFI) & 0.95 & 0.94 & 0.95 & 0.90 이상 \\
\hline 표준부합지수(NFI) & 0.87 & 0.86 & 0.87 & 0.90 이상 \\
\hline 수정부합지수(AGFI) & 0.85 & 0.84 & 0.85 & 0.90 이상 \\
\hline 간명기초부합지수(PGFI) & 0.69 & 0.69 & 0.69 & 클수록 간명함 \\
\hline 표준(Normed) $\times 2$ & 1.312 & 1.413 & 1.352 & $1.0-2.0 / 3.0$, 최대 5.0 \\
\hline 간명표준부합지 수(PNFI) & 0.73 & 0.73 & 0.73 & 콜수록 좋음, 0.6 이상 \\
\hline Model 아카이케(AIC) & 593.82 & 624.12 & 606.50 & $\begin{array}{l}\text { 0에 가까울수록 우수, } \\
\text { 대립모델 비교 이용 }\end{array}$ \\
\hline
\end{tabular}




\section{2 .3 가설검중 및 결과 해석}

제안모델의 경로계수를 보면, 사용의 용이함은 사용의도에도 유의하게 영향올 미치고 있으며 $(\mathrm{t}<0.05)$, 유용성에도 유의하게 영향을 미치고 있고 $(\mathrm{t}<0.01)$, 긍정적 감정에도 유의하게 영향을 미치고 있다(t<0.05). 신뢰는 유용성에 어느 정도 긍정적으로 영향을 주고 있고 $(\mathrm{t}<0.1)$, 긍정적 감정에는 유의하게 긍정적으로 영향을 주고 있다 $(\mathrm{t}<0.01)$. 긍정적 감정은 유용성에 유의하게 영향을 미치고 있다 $(\mathrm{t}<0.05)$. 그 외 다른 변수간에는 유의한 관계가 성립되지 않았다. 각 변수들의 경로계수는 <그림 $2>$ 에 제시되어 있다.

<그립 2> 변수들간의 구조 관계

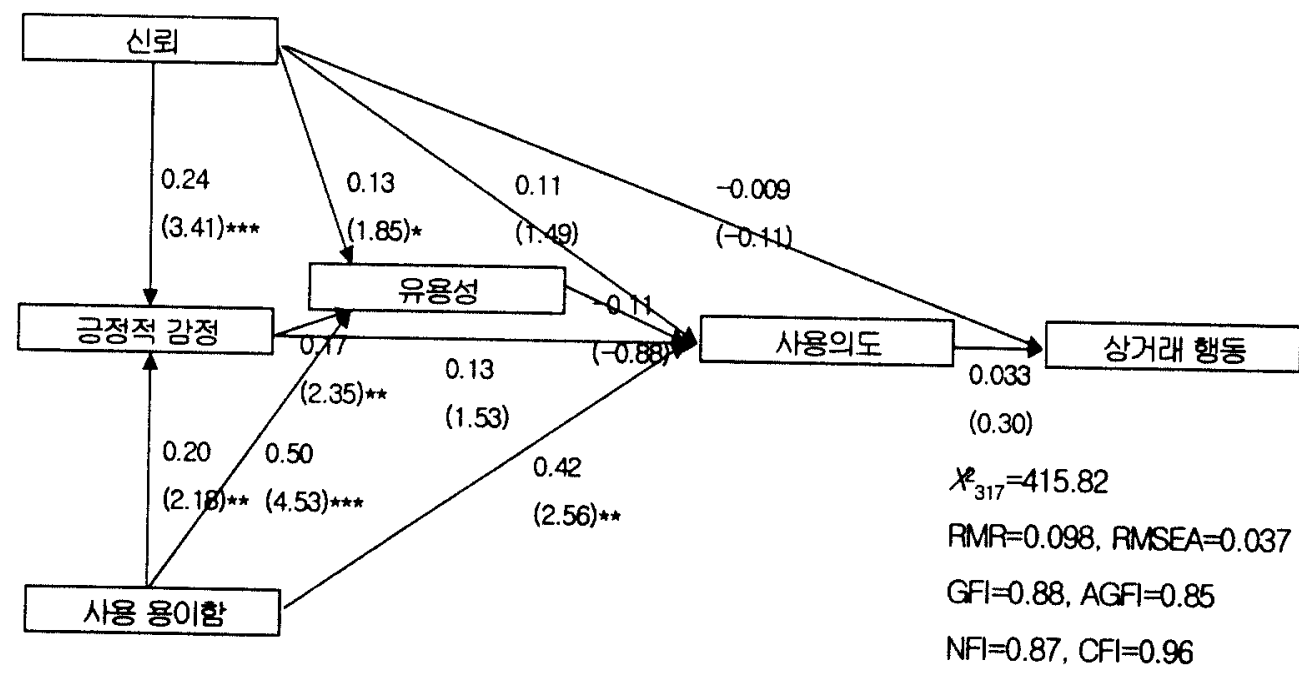

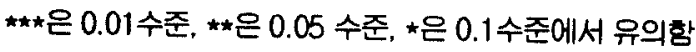

가설 검중 결과는 <표 7>에 제시되어 있다. 열 한 개 가설 중 다섯 개가 채택되었고, 한 개는 한계적 지지로 나타넜으며, 다섯 개는 기각되었다.

<표 7> 가설검중 결과

\begin{tabular}{|c|c|c|}
\hline 관계 & 가설 & 결과 \\
\hline \multirow{3}{*}{$\begin{array}{l}\text { 유용성, } \\
\text { 용이함, } \\
\text { 수용의도 }\end{array}$} & $\begin{array}{l}\text { 1. 온라인 상거래 사이트(시스템)에 대한 유용성 지각은 } \\
\text { 사용의도에 정적으로 영향을 줄 것이다. }\end{array}$ & 기각 \\
\hline & $\begin{array}{llrr}2 . & \text { 온라인 상거래 사이트(시스템)에 대한 } & \text { 사용의 } \\
\text { 용이함 지각은 사용의도에 정적으로 영향올 줄 것이다. } & \end{array}$ & 채택 \\
\hline & $\begin{array}{l}\text { 3. 온라인 상거래에서 사이트(시스템)에 대한 사용의 용이함 } \\
\text { 지각은 유용성 지각에 정적으로 영향을 줄 것이다. }\end{array}$ & 채택 \\
\hline
\end{tabular}




\begin{tabular}{|c|c|c|}
\hline $\begin{array}{l}\text { 수용의도, } \\
\text { 행동 }\end{array}$ & $\begin{array}{l}\text { 4. 온라인 상거래 사이트(시스템) 사용의도는 상거래 행동에 } \\
\text { 정적으로 영향을 줄 것이다. }\end{array}$ & 기각 \\
\hline $\begin{array}{l}\text { 신뢰, } \\
\text { 유용성 }\end{array}$ & $\begin{array}{l}5 . \text { 온라인 상거래 관련자와 시스템에 대한 신뢰는 } \\
\text { 사이트(시스템)의 유용성 지각에 정적으로 영향을 줄 것이다. }\end{array}$ & 한계적 \\
\hline $\begin{array}{l}\text { 신뢰, } \\
\text { 의도 }\end{array}$ & $\begin{array}{l}\text { 6. 온라인 상거래에서 관련자와 사이트(시스템)에 대한 신뢰는 } \\
\text { 사용의도에 정적으로 영향을 줄 것이다. }\end{array}$ & 기각 \\
\hline $\begin{array}{l}\text { 신뢰, } \\
\text { 행 동 }\end{array}$ & $\begin{array}{l}\text { 7. 온라인 상거래 관련자와 사이트(시스템)에 대한 신뢰는 상거래 } \\
\text { 행동에 정적으로 영향을 줄 것이다. }\end{array}$ & 기각 \\
\hline $\begin{array}{l}\text { 긍정감정, } \\
\text { 유용성 }\end{array}$ & $\begin{array}{l}\text { 8. 온라인 상거래에서 긍정적 감정은 유용성 지각에 정적으로 } \\
\text { 영향을 줄 것이다. }\end{array}$ & 채택 \\
\hline $\begin{array}{l}\text { 긍정감정, } \\
\text { 의도 }\end{array}$ & $\begin{array}{l}\text { 9. 온라인 상거래에서 긍정적 감정은 상거래 의도에 정적으로 } \\
\text { 영향을 줄 것이다 }\end{array}$ & 기각 \\
\hline $\begin{array}{l}\text { 옹이함, } \\
\text { 긍정감정 }\end{array}$ & $\begin{array}{l}10 . \text { 온라인 상거래에서 사용 용이함 지각은 긍정적 감정에 } \\
\text { 정적으로 영향울 줄 것이다. }\end{array}$ & 채택 \\
\hline $\begin{array}{l}\text { 신뢰와 } \\
\text { 감정 }\end{array}$ & $\begin{array}{l}\text { 11. 온라인 상거래에서 신뢰는 긍정적 감정에 정적으로 영향올 줄 } \\
\text { 것이다. }\end{array}$ & 채 택 \\
\hline
\end{tabular}

가설 1 은 기각되었고, 가설 2 와 가설 3 은 채택되었다. 첫쩨, 사이트에 대한 유용성 지각은 온라인 사이트(시스템) 사용의도에 정적으로 영향을 주지 않는 것으로 나타넜다. 둘째, 사이트에 대한 사용의 용이함 지각은 사이트 사용의도에 정적으로 영향을 주었다. 셋째, 사이트의 사용 용이함 지각은 유용성에 정적으로 유의한 영향을 주었다.

사용의 용이함 지각이 사용의도와 유용성에 정적으로 유의하게 영향을 주는 것으로 나타난 결과는 기존 연구의 결과들과 일치한다. 즉 온라인 상거래에서 사용 용이함은 중요한 변수가 됨을 알 수 있다. 유용성이 사용의도에 영향울 주지 않는 것으로 나타난 이유를 추론할 필요가 있다. 원인으로 생각할 수 있는 것은 조사에 참여한 학생들이 인터넷을 통해 상거래를 하는 것 자체에 대해 오프라인 상거래에 비해 유용성을 높게 지각하지 않을 수 있다는 점이다. 즉, 학생들이 온라인을 통해 상거래를 하는 동기는 상거래의 유용성에 있다기보다 온라인을 통해 상거래를 하는 편리함 그 자체에서 나온다고 추론할 수 있다.

가설 4 는 기각되었다. 즉, 온라인 상거래 의도는 상거래 행동에 유의하게 정적으로 영향을 주지 않았다. 이러한 결과에 대해서는 원인을 분석해야 할 필요성이 있다. 첫 번째로 고려할 수 있는 원인은 조사를 하는 시기와 실제 행동을 하는 시기와의 괴리이다. 태도와 행동의 관계를 높이기 위해서는 행동이 발생하는 시점에 가장 가까운 시기에 측정해야 한다. 즉 온라인 상거래를 하는 과정에서 측정을 해야 의도와 온라인 행동과의 관계에 대한 정확도를 높일 수 있다. 두 번째로 생각할 수 있는 원인으로, 피조사자들이 온라인 상거래를 하는 과정에서 형성되었던 지각 요소들이 조사를 하는 때는 정확하게 유지되지 않았다고 볼 수 있다. 이러한 현상은 개인들은 새로운 상거래 상황이 생기면 과거의 상거래 경험 자체에 집착하기보다 상거래 경험을 바탕으로 새로운 탐색과정을 거칠 수 있음을 의미한다.

가설 5 는 한계적으로 지지되었지만 가설 6 과 가설 7 은 기각되었다. 신뢰는 유용성 지각에 어느 정도 정적으로 영향을 주는 것으로 나타났지만 온라인 상거래 시스템 사용의도와 상거래 행동에 정적으로 영향을 주지 않았다. 이 것은 신뢰가 인터넷 쇼핑예서 유용성과 
수용의도에 영향올 미치는 중요한 요소로 나타난 기존 연구의 결과와 다르다. 이러한 결과를 바탕으로 신뢰와 사이트 사용의도와의 관계롤 그대로 해석하면, 대학생 온라인 쇼핑자들은 온라인 상거래 업체에 대한 신뢰와 관계없이 사이트를 사용할 의도를 형성할 수 있는 것으로 볼 수 있다. 그렇지만, 신뢰는 긍정적 감정을 통해서 유용성에 유의하게 영향을 미치는 것으로 나타났으므로, 신뢰는 온라인 상거래가 이루어지는데 있어서 긍정적 감정올 높이는 기본적인 요소로 간주될 수 있다. 또는 웅답자들은 온라인 상거래를 하면서 사이트 자체의 신뢰에 대해서는 심각하게 생각하지 않을 수도 있다.

가설 8 은 채택되었고 가설 9 는 기각되었다. 긍정적 감정은 유용성을 지각하는데 정적으로 유의하게 영향을 주었다. 그렇지만, 긍정적 감정은 사이트 사용의도에 정적으로 유의하게 영향을 미치지 않았다. 긍정적 감정이 유용성을 높이는데 영향을 주지만, 사이트 사용의도에까지 직접적으로 영향을 미치지는 못함을 알 수 있다.

가설 10 은 채택되었다. 즉, 사용의 용이함은 긍정적 감정에 정적으로 유의하게 영향을 주었다. 이 것은 사람들이 특정 사이트를 사용하기 쉅다고 지각하면 긍정적 감정이 발생할 수 있음을 의미한다.

가설 11 은 채택되었다. 신뢰는 긍정적 감정에 유의하게 정적으로 영향을 주는 것으로 나타났다. 즉 개인이 특정 온라인 상거래 사이트를 신뢰하게 되면 그 사이트에 대해 긍정적 감정을 갖게 됨을 알 수 있다. 그리고 이러한 결과를 톻해 신뢰는 긍정적 감정에 매개되어 상거래 사이트의 유용성을 높게 지각할 수 있음을 알 수 있다.

\section{4. 결론}

인터넷은 정보통신기술을 바탕으로 한 혁신제품이라는 점에서 인터넷 관련 분야의 수용을 설명하는데 혁신기술의 수용에 대한 기술수용모델(TAM)의 구조를 적용할 수 있다. TAM의 핵 심이 되는 두 가지 개념은 유용성과 사용의 용이함으로 인터넷관련 혁신 제품의 수용에 관 한 연구들(예를 들면, 월드와이드웹(www) 사용, 인터넷 사이트 구성, 인터넷 쇼평, 인터넷 뱅 킹에 관한 연구)에 의하면 유용성과 사용의 용이함 두 신념은 사용의도에 영향을 주는 것으 로 나타났다. 그리고 일부 연구에서 사용의 용이함은 유용성 지각에도 영향을 주는 것으로 나타났다. 그러므로 기업체에서 일하는 사람들의 혁신적 시스템 수용을 설명하기 위해 적용 됐던 TAM의 구조는 온라인 상거래에도 적용될 수 있다.

그렇지만 TAM은 원래 목적이 혁신적인 기술제품을 설명하는 것이기 때문에 온라인 상거래 의 수용을 정확하게 설명하기 위해서는 인터넷과 상거래에서 발생하는 특섬을 반영해야 한 다. 사람들이 온라인 상거래를 수용하는 구조를 통합적으로 파악해야 온라인 상거래의 수용 에 대한 관계구조를 명확하게 하고 설명력을 높일 수 있다. 인터넷 관련 연구들에서 적용되 었던 유용성과 사용 용이함의 구조에 신뢰와 감정 요인을 퉁합하였다. 기존 연구들에 의하 면 신뢰는 온라인 상거래에서 가장 중요하게 고려되는 요소이다. 신뢰는 온라인 상거래에서 유용성을 지각하는데 영향을 주고 온라인 상거래의 수용의도에 영향을 주었다. 감정은 개인 의 태도를 구섬하는 변수이며 쇼핑에 영향을 주기 때문에 온라인 상거래에 대한 수용에 있 어서도 감정의 영향을 반영할 필요가 있다. 온라인 상거래자의 수용을 고려하기 위해 긍정 적 감정을 중심으로 변수들의 영향관계를 파악하였다.

변수들의 인과관계를 고려하여 구조화된 모델을 제안하였다. 그리고 다른 관점예서 제안 
가능한 대안모델을 제시하였다. 대안모델 1은 태도에 대한 일차차원 견해를 바탕으로 구조화하였다. 그리하여 긍정적 감정을 태도의 구성요소로 간주하여 태도가 인지적 요소들의 영향을 받아 상거래 사이트의 사용의도에 영향을 미치는 유일한 변수로 보는 것이다. 대안모델 2 는 신뢰와 긍정적 감정이 각기 개발적으로 형성된다고 보는 것이다. 그리하여 신뢰와 긍정적 감정이 서로 영향을 미치지 않는다고 보았다. 모델들을 비교한 결과 제안 모델은 다른 대안 모델보다 우수하였다.

제안 모델을 중심으로 가설을 검증한 결과에 의하면, 대부분의 기존 연구들이 온라인 상거래 수용에서 신뢰만 강조한 반면, 본 연구에서는 긍정적 감정과 사용 옹이함도 온라인 상거래의 수용에서 중요하게 영향을 주는 변수로 나타났다. 그리고 사용의 용이함은 사이트 사용의도에 정적으로 유의하게 영향을 주는 것으로 나타났지만 긍정적 감정과 유용성은 사용의도에 유의하게 영향을 미치지 않았다. 또한 소비자들은 긍정적 감정과 사용의 용이함은 유용성 지각에 유의하게 영향을 주며 신뢰도 어느 정도 유용성에 영향을 주지만, 그러한 유용성 지각이 사이트 사용의도와 상거래 행동으로까지 연결되지는 않는 것으로 나타났다. 기존 연구들을 볼 때, 유용성 지각과 사이트 사용의도 간에 관련성이 없다고 판단하기 보다 온라인 상거래 경영자는 신뢰와 긍정적 감정이 유옹성 지각을 통해 사이트 의도를 높게 만들 수 있는 방안을 강구해야 하며, 동시에 신뢰와 긍정적 감정 자체로도 사용의도에 영향을 줄 수 있는 방안을 찾아야 할 것이다.

온라인 상거래의 수용에 관한 통합구조는 온라인 상거래의 수용을 설명하는데 시사점을 제공할 것이다. 온라인 상거래 수용 구조를 통합적을 확장하는 과정을 통해 온라인 상거래 의 수용에 대해 개별적으로 실시되어온 연구들을 체계화하고 개념들의 인과관계를 파악할 수 있다. 그리고 경영자들은 온라인 상거래 수용관계를 파악하여 마케팅 전략을 수립하기 위한 실무적인 지침을 제공받을 수 있다

본 연구는 이론연구와 실증연구에서 한계점을 가지고 있다. 이론 측면에서 기존의 연구들을 통합하는 형태를 취했기 때문에 변수간의 관계에서 복잡성이 있고 인과간계의 설명에서 다른 의견이 제시될 수 있다. 그리고 인터넷 상거래의 수용을 더욱 포괄적으로 설명하기 위해서는 본 연구를 보완해서 신제품 수뵹의 주요 요인들로 알려진 상대적 이점, 호환성, 복잡성, 시험가능성, 관찰가능성 등을 고려하는 연구를 미래의 연구방향으로 할 수 있다.

실증연구에서, 측정 값이 조사 시기에 의해 영향을 받을 수 있고 조사 대상자들이 학생이라는 특정 집단에 한정되어 있기 때문에 실증연구의 결과를 일반화하는 데는 제한적 요소가 있다. 첫째, 태도와 행동의 측정에 대한 문제를 제기할 수 있는대, 특히 상거래 행동을 측정하는 문제를 해결하지 못하였다. 상거래 행동을 측정한 문항들의 신뢰도가 낮게 나타났는데, 추후 연구에서는 상거래 행동을 촉정할 수 있는 신뢰도 높은 다수의 문항들을 개발하여 모델을 검증할 필요가 있다. 둘째, 피조사자 선정의 문제이다. 학생들을 대상으로 인터넷 쇼핑을 측정하였는데, 학생들은 일반 인터넷 쇼핑자를 대표하지 못한다. 정확한 연구를 하기 위해서는 사람들이 온라인 상거래 행동을 하는 과정에 있을 때 조사를 하여 다시 검증할 필요가 있다. 


\section{<참고문헌>}

김기범, 김미희, 최상진(2001), "정서적 고독감과 인터넷 효능감이 온라인 커뮤케이션

활동에 미치는 영향: 남녀대학생을 중심으로", 한국심리학희지: 여성, 6(2), 39-57.

김명소(1999), "인터넷 항해과정의 flow모형 및 flow-구매의도 모형에서의 성차연구",

한국심리확혀지: 여성, 4(1), 27-40.

김상용, 박성용(1999), "전자상거래에서의 구매의도 결정영향요인에 관한 연구",

소비자학연구, $10(3), 45-66$.

김영찬, 이두회(2002), "인터넷 사용자가 모두 인터넷 구매자인가?", 소비자학연구, 13(1), 233-256.

김정수, 김영걸(2002), "인터넷 뺑킹에서 고객이 인지하는 가치가 고객 충성도에 미치는 영향", 경영정보학연구, 12(4), 215-235.

김재휘(2001), "사이트에 대한 몰입과 태도에 따른 인터넷 배너광고 노출효과에 관한 연구",

광고학연구: 일반, $12(1), 173-197$.

김재휘, 한미영, 김현주(2002), "인터넷 서점 이용자의 웹서비스에 대한 평가가 브랜드 신뢰

및 로열티에 미치는 영향", 한국심리학희지: 소비자·광고, 33-51.

김재회, 훙재욱(2000), "인터넷 이용자들의 동기와 사이트 이용행동", 한국심리화희지:

소비자· 광고, 192), 25-46.

김훈, 권순일(1999), "인터넷 사용자의 라이프스타일과 구매의사결정에 관한 탐색적 연구",

경영하연구, 28(2), 353-372.

문병준, 손옹석(2000), "인터넷을 통한 소비자 정보탐색 및 구매행동에 영향을 주는 요인:

개념적 연구", 소비자학연구, 11(4), 131-151.

박철(2002), "기업과 소비자간(B-to-C) 전자상거래에서 소비자 신뢰형성 요인에 관한 연구",

소비자학연구, 13(2), 207-234.

박순창, 정경수, 이재록(2000), "인터넷 수용요인에 관한 실증적 연구", 경영학연구, 29(4),

885-909.

박유식, 한명회(2001), "인터넷 쇼평몰에서 위헙지각과 품질지각이 구매의도에 미치는 영향:

보증신뢰성, 지각된 정보의 양, 주관적 지식을 중심으로", 마케팅연구, 16(1), 59-84.

배병렬(2002), “구조방정식모델 이해와 활용”, 대경, 서울

서건수(2001), "인터넷 쇼핑몰의 특성과 사용자 수용간의 상황적 관계분석", 경영정보학연구,

11(2), 23-55.

서문식, 김상희(2002), "인터넷 쇼핑몰 특징과 감정적 반웅과의 관계에 관한 연구",

마케팅연구, 17(2), 113-145.

서문식, 김상희, 서용한(2002), "인터넷 쇼핑상황에서 경헙하는 소비자 감정에 관한 질적

연구", 소비자확연구, 13(2), 47-79.

성한기, 김미련(1998), "감정과 소비자 행동", 대구효성가톨릭대 사화과화연구, 145-171.

손달호(2001), "TAM 이론에서 심리학적 요인들의 역할", 한국경영과학회지, 26(1), 1-14

신기영, 추교완, 박동진(2001), "인터넷쇼핑몰 이용에 영향을 미치는 요인에 관한 연구",

정보시스템연구, 10(1), 279-301.

양희동, 강소라(2002), "TAM에서의 태도 개념 측정 개선과 WWW 사용의 설명력" , 경영학연구,

31(4), 929-950. 
유창조(1996), "쇼핑행위의 경험적 측면: 쇼핑시 느끼는 기분이나 감정이 매장 태도와 구매

의사에 미치는 영향에 관한 연구", 소비자학연구, 7(1), 51-73.

유창조, 현소은, 전중옥(1997), "매장의 특징, 매장내 감정 및 쇼푕 행위에 관한 구조적

연구", 마케팅연구, 12(2), 1-27.

유현정, 김기옥(2000), "전자상거래에서의 소비자만족도 척도개발", 소비자학연구, 11(3),

87-107.

윤철호, 김상혼(2003), "전자상점 수용모형에 관한 실증적 연구", 한국경영정보확회 2003

춘계학술대희 논문집, $937-946$.

이건창, 정남호(2000), 국내 인터넷 주식거래를 위한 비즈니스 모델에 관한 실증연구" ,

경영정보학연구, $10(2), 125-147$.

이건창, 정남호, 이종신(2002), "국내 인터넷 뱅킹 사용자의 이용의도에 영향을 미치는

요인간 관계에 관한 실증연구", 경영정보학연구, 12(3), 191-212.

이문규, 최은정(2001), "인터넷 쇼펑에 따른 소비자의 위험 지각에 관한 탐색 연구",

한국마케팅저널, 2(4), 26-53.

이상윤, 박광태(2001), "인터넷 뱅킹의 서비스 품질결정 요인에 관한 탐색적 연구", 2001

한국서비스경영학희 추계학술대회 발표논문집, $36-52$.

이학식, 임지훈(2002), "소비관련 감정척도의 개발", 마케팅연구, 17(3), 55-91.

이호배, 정주훈, 박기백(2000), "인터넷 사이트에 대한 속성신넘과 태도가 흠페이지

광고효과에 미치는 영향", 경영학연구, 29(2), 263-290.

임종원 편저(1996), “마케팅조사 이렇게”, 법문사, 서울

전종근, 홍성태(2003), "인터넷쇼핑에서 구매이후의 평가속성이 재구매의도에 미치는 영향",

경영학연구, 31 (7, 특별호), 1765-1786.

제진훈, 박윤재, 김광용(2002), "금융서비스 유통상의 혁신수용에 관한 연구; 인터넷뱅킹을 중심으로", 유통연구, 7(1), 61-86.

최인혁, 박주영, 이철선(2002), "온라인(Online) 상에서의 제품유형에 따른 소비자의 브랜드의존성", 유통연구, 6(20, 109-133.

Ambler, Tim(1997), "How much of brand equity is explained by trust", Management Decision, Vol. 35(4), 283-292.

Anand, Punam, Morr is B. Holbrook, and Debra Stephens(1988), "The Format ion of Affect ive Judgment: The Cognit ive-Af fect ive Model versus The Independence Hypothes is", Journal of Consumer Research, Vol. 15(December), 386-391.

Atuahene-Gima, Kwaku and Haiyang Li(2002), "When Does Trust Matter? Antecedents and Cont igent Effects of Supervisee Trust on Performance in Selling New products in China and the United States", Journal of Marketing, Vol. 66(July), 61-81.

Batra, Rajeev and Dougl as M. St ayman (1990), "The Role of Mood in Advert i s ing Ef fect i veness", Journal of Consumer Research, Vol. 17(September), 203-214.

Berry, Leonard L. (1996), "Retai lers wi th a Future", Market ing Management, Vol . 5(Spring), $39-46$.

Burke, Mari an Chapman and Julie A. Edel 1(1989), "The Impact of Feel ings on Ad-Based Affect and Cognition", Journal of Marketing Research, Vol. 26(February), 69-83.

Chau, P. Y. K. G. Au. and K. Y. Tam(2000), "Impact of Information Presentation Modes on 
Online Shopping: An Empirical Evaluat ion of a Broadband Interact ive Shopping Service", Journal of Organizational Computing and Electronic Commerce, Vol. 10(1), 1-22.

Cohen, Joel B. and Charles S. Areni(1991), "Affect and Consumer Behavior", in Handbook of Consumer Behavior. Thomas S. Robertson and Harold H. Kassarjian, ed. New York: Prent ice Hall.

Davis, F. D. (1989), "Perceived Usefulness, Perceived Ease of Use, and User Acceptance of Informat ion Technology", MIS Quarterly, Vol. 13(3), 319-340.

Davis, F. D., R. P. Bagozzi, and P. R. Warshaw(1989), "User Acceptance of Computer Technology: A Compar ison of Two Theoret ical Models". Management Science, Vol. 35(8), 982-1003.

Davis, Fred D. and Viswanath Venkatesh(1996), "A Critical Assessment of Potential Measurement Biases in The Technology Acceptance Model: Three Experiments", Int. J. Human-Computer Studies, 45. 19-45.

Dawson, S., P. H. Bloch, and N. M. Ridgway(1990), "Shopping Mot ives, Emotional States, and Retail Outcomes", Journal of Retailing, Vol. 60(Winter), 408-427.

Delgado-Ballester. Elena and Jose Luis Munuera-Aleman(2000), "Brand trust in the context of consumer loyalty". European Journal of Marketing, Vol. 35(11/12), 1238-1258.

Dishaw, Mark T. and Diane M. Strong(1999), Extending the Technology Accept ance Model with Task-technology fit Constructs" , Information \& Management, Vol. 36, 9-21.

Donovan, Robert J. and John R. Rossiter(1982), "Store Atmosphere: An Environmental Psychology Approach", Journal of Retailing, Vol. 58(Spring), 34-57.

Edel1. Julie A. and Marian Chapman Burke(1987), "The Power of Feelings in Understanding Advertising effect", Journal of Consumer Research, Vol. 14(December), 421-433.

Frost, Taggart, David V. St impson, and Micol R. C. Maughan(1978), "Some Correlates of Trust", The Journal of Psychology, 99. 103-108.

Ganesan, S. (1994), "Determinants of Long-Term Orient at ion in Buyer-Sel ler Relat ionships", Journal of Marketing, Vol. 58(April) 1-19.

Gardner, Mery P.(1985), "Mood States and Consumer Behavior: A Critical Review", Journal of Consumer Research, Vol. 12(December), 281-300.

Gardner, Mery P. and Dennis Rook(1988), "Effects of Impulse Purchase on Consumers' Affective States", in Michael J. Houston, ed., Advances in Consumer Research Vol. 15. 127-130.

Gefen, David(2000), "E-Commerce: The Role of Familiarity and Trust", Omega, 28(6), 725-737.

Gefen, David, and D. W. Straub(2000), "The Relative Importance of Perceived Ease-of-Use in IS Adoption: A Study of E-Commerce Adoption", Journal of the Association for Information Systems, Vol. 1(8), 1-30.

Gefen, David, Elena Karahanna, and Detmar W. Straub(2003), "Trust and TAM in Online Shopping: An Integrated Model", MIS Quarterly, Vol. 27(1), 51-90.

Gorn, G. J.(1982), "The effects of Music in Advert ising on Choice Behavior: A Classical Conditioning Approach", Journal of Marketing, Vol. 46. 94-101. 
Hirschman, E. C. and M. B. Holbrook(1982), "Hedonic Consumption: Emerging Concepts, Methods and Propositions", Journal of Marketing, Vol. 46, 92-101.

Holbrook, M. B. and R. Batra(1987), "Assessing The Role of Emot ions as Mediat ors of Consumer Responses to Advertising", Journal of Consumer Research, Vol. 14, 404-420.

Hong, Weiyin, James Y. L. Thong, Wai-man Hong, and Kar-Yan Tam(2002), "Determinants of User Acceptance of Digital Libraries: An Empirical Examination of Individual Differences and System Characteristics", Journal of Management Information Systems, Winter 2001-2002, Vol. 18(3), 97-124.

Howard, Daniel J. and Charles Gengler(2001), "Emotional Contagion Effects on Product Att itudes", Journal of Consumer Research, Vol. 28(September), 189-201.

Isen, A. M.(1984), "The influence of positive affect on decision making and cognitive organization" Advances in Consumer Research, Vol. 11, 534-537.

Izard, Carroll(1992), "Basic Emotions, Relations Among Emotions, and Emotion-Cognition Relations", Psychological Review, Vol. 99(3), 561-565.

Jor eskog, K. G. and D. Sorbum(1989), LISREL 7-A Guide to The Progr am and Appl icat ions ( $2^{\text {nd }}$ ), SPSS Publications, Chicago.

Karahanna, E. and D. W. Straub(1999) “The Psychological Origins of Perceived Usefulness and Perceived Ease-of-Use", Information \& Management, Vol. 35, 237-250.

Koufaris, Marios(2002), "Applying the Technology Acceptance Model and Flow Theory to Online Consumer Behavior", Information Systems Research, Vol. 13(2), 205-223.

Laverie, Debra A., Robert E. Kleine III, and Susan Schultz Kleine(1993), "Linking Emotions and Values in Consumption Experiences", Advances in Consumer Research, Vol . 20, 70-75.

Lederer, Albert L., Donna J. Maupin, Mark P. Sena, Youlong Zhuang(2000), "The Technology Acceptance Model and The World Wide Web", Decision Support Systems, 29, 269-282.

Legris, Paul, John Ingham, and Pierre Collerette(2002), "Why do people use information technology? A critical review of the technology acceptance model", Information \& Management, 1-14.

Mayer, Roger C., James H. Davis, and F. David Schoorman(1995), "An Integrative Model of Organizational Trust", Academy of Management Review, Vol. 20(3), 709-734.

McAllister, D. J.(1995), "Affect and Cognition Based Trust as Foundations for Interpersonal Cooperation in Organizations", Academy of Management Journal, Vol. 38(February), 24-59.

Michell, Paul, John Reast and James Lynch(1998), "Exploring The Foundations of Trust", Journal of Marketing Management, 14, 159-172.

Moorman, Christine, General Zaltman, and Rohit Deshpande(1992), "Relationahips Between Providers and Users of Market Research: The dynamics of Trust Within and Between Organizations", Journal of Marketing Research, Vol. 29(August), 314-328.

Morgan, Robert M. and Shelby D. Hunt (1994), "The Commitment-Trust Theory of Relat ionship Marketing", Journal of Marketing, Vol. 58(July), 20-39.

Oliver, Richard L. (1993), "Cognitive, Affective, and Attribute Bases of the Sat isfaction Responses", Journal of Consumer Research, 20(December), 418-430.

\section{4 한국마케팅저널 제 6 권 1호}


Peterson, R. A., S. A. Balasubramanian, and B. J. Bronnenberg(1997), "Exploring the Implications of The Internet for Consumer Marketing", Journal of the Academy of Marketing Science, Vol. 25(4), 329-346.

Petty, R. E., J. T. Cacioppo, and J. R. Goldman(1981), "Personal Involvement as Determinant of Argument-Based Persuasion", Journal of Personality and Social Psychology, Vol . 40, 847-855.

Raveld, A. and C. Gronroos(1996), "The Value Concept and Relat ionship Market ing", European Journal of Marketing, Vol. 20(2), 19-30.

Reichheld, F. F., and P. Schefter(2000), "E-Loyalty: Your Secret Weapon on the Web", Harvard Business Review, Vol. 78(4), 105-113.

Rempel, J. K. J. G. Holmes, and M. P. Zanna(1985), "Trust in close relationships", Journal of Personality and Social Psychology, Vol. 49(1), 95-112.

Rotter, J. B.(1971), "Generalized Expectations for Interpersonal Trust", American Psychologist, Vol. 26(May), 443-450.

Russell, James A.(1991), "Culture and the Categorization of Emotions", Philssophical Bullet in, Vol. 110(November), 1161-1178.

Ruth, Julie A. (2001), "Promoting a Brand's Emotion Benefits: The Influence of Emotion Categor izat ion Processes on Consumer Evaluations, "Journal of Consumer Psychology, Vol . 11(2), 99-113.

Schachter, Stanley and Jerome E. Singer(1962), "Cognitive, Social, and Psychological Determinants of Emotional States", Psychological Review, Vol. 69(June), 379-399.

Simon, H. A. (1967), "Motivational and Emotional Controls of Cognition", Psychological Review, Vol. 74, 29-39.

Sirdeshmukh, Deepak, Jagdip Singh, and Barry Sabol(2002), "Consumer Trust, Value, and Loyalty in Relational Exchanges", Journal of Marketing, Vol. 66(January), 15-37.

Straub, Detmar, Mark Keil, and Walter Brenner(1997), "Test ing The Technology Accept ance Model Across Cultures: A Three Country Study", Information \& Management, 33, 1-11.

Swinyard, William T.(1993), "The Effect of Mood, Involvement, and Quality of store Experience on Shopping Intention", Journal of Consumer Research, Vol. 20(September), 271-280.

Torkzadeh, Gholamreza and Gurpreet Dhillon(2002), "Measuring Factors that Influence the Success of Internet Commerce". Information Systems Research, Vol. 13(2), 187-204.

Venkatesh, Viswanath(2000). "Determinants of Perceived Ease of Use: Integrat ing Control, Intrinsic Motivation, and Emotion into the Technology Acceptance Model". Information Systems Research, Vol. 11(4), 342-365.

Venkatesh, Viswanatha and Fred D. Davis(1996), "A Model of the Antecedents of Perceived Ease of Use: Development and Test", Vol. 27(3), Decision Sciences, 451-481.

Venkatesh, Viswanatha and Fred D. Davis(2000), "A Theoret ical Extension of the Technology Acceptance Model: Four Longitudinal Field Studies" Management Science, Vol. 46(2), 186-204.

Watson, David and Auke Tellgen(1985), "Toward a Consensual Structure of Mood", 온라인 상거래 수용에 관한 통합적 확장: 기술수용모델에 대한 신뢰와 감정의 결합 85 
Psychological Bulletin, Vol. 98, 219-235.

Weinberg, P. and W. Gottwald(1982), "Impulsive Consumer Buying as a Emotions", Journal of Business Research, Vol. 10, 43-57.

Wicks, Andrew C. Shwan L. Berman, and Thomas M. Jones(1999), "The Structure of Optimal Trust: Moral and Strategic Implications", Academy of Management Review, Vol. 24(1), 99-116.

Yoo, Changjo, Jonghee Park, and Deborah J. MacInnis(1995), "The Effects of Store Characteristics and In-Store Emotional Experiences on Store Attitudes", Journal of Business Research, 253-263.

Zajonc, Robert B. (1980), "Feeling and Thinking: Preference Need No Inferences", American Psychologist, Vol. 35, 151-175.

Zajonc, Robert B. and Hazel Markus (1982), "Af fect ive and Cognit ive Factors in Preferences", Journal of Consumer Research, Vol. 9(2), 121-131. 